\title{
The Hostage Crisis and the "Hostage Act"
}

\author{
Abner J. Mikva $\dagger$ and Gerald L. Neuman $\dagger \uparrow$
}

The handling of the Iranian hostage crisis ${ }^{1}$ by two Presidents triggered a constitutional red alert in the ranks of the federal judiciary in the spring of 1981 . The dominant theme in the ensuing litigation was the separation of powers: President Reagan's failure to seek congressional authorization in implementing President Carter's eleventh-hour settlement of the crisis ${ }^{2}$ made the legitimacy of his orders depend on inherent executive powers and earlier legislation enacted without the Iranian affair in mind. ${ }^{3}$ The

$\dagger$ Judge, United States Court of Appeals for the District of Columbia Circuit. J.D., University of Chicago Law School, 1951.

if Associate, Foley, Hoag \& Eliot, Boston, Massachusetts. J.D., Harvard Law School, 1980. Mr. Neuman served as law clerk to Judge Mikva during the time of the litigation over the hostage crisis.

1 The crisis arose from the seizure of American diplomatic personnel at the United States embassy in Tehran on November 4, 1979, and their subsequent detention under Iranian government auspices until January 20, 1981. See, e.g., Dames \& Moore v. Regan, 101 S. Ct. 2972, 2978-79 (1981).

The American hostages were released on January 20, 1981, the day of President Reagan's inauguration, pursuant to an agreement reached the previous day. See id. at 2979. This agreement was set out in two declarations of the Algerian government, which had assisted in negotiating the release. See Declaration of the Government of the Democratic and Popular Republic of Algeria, Jan. 19, 1981, reprinted in DeP'T STATE BulL., Jan. 1981, at 13 [hereinafter cited as Declaration I]; Declaration of the Government of the Democratic and Popular Republic of Algeria Concerning the Settlement of Claims by the Government of the United States of America and the Government of the Islamic Republic of Iran, Jan. 19, 1981, reprinted in DeP'T STATE BULL., Jan. 1981, at 3-4 [hereinafter cited as Declaration II]. One district court thought President Carter's executive orders implementing the agreement were of dubious validity because they did not take effect until after he had left office. See Electronic Data Sys. Iran v. Social Sec. Org., 508 F. Supp. 1350 (N.D. Tex. Feb. 12, 1981), petition for cert. before judgment denied, $101 \mathrm{~S}$. Ct. 3067 (June 8, 1981), aff'd in part and vacated in part, 651 F.2d 1007 (5th Cir. July 15, 1981), but the issue was later mooted when President Reagan promulgated his own executive order on February 24, ratifying the earlier orders. Exec. Order No. 12,294, 46 Fed. Reg. 14,111 (1981).

see Dames \& Moore v. Regan, 101 S. Ct. 2972, 2978-82 (1981); American Int'l Group, Inc. v. Islamic Republic of Iran, 657 F.2d 430, 437-39 (D.C. Cir. 1981); Charles T. Main Int'l, Inc. v. Khuzestan Water \& Power Auth., 651 F.2d 800, 805-06 (1st Cir. 1981). The constitutional attacks focused particularly on the President's agreement to submit billions of dollars of American claims against Iran to binding arbitration. See Dames \& Moore, $101 \mathrm{~S}$. Ct. at 2986-92. The authority of the federal government to settle claims of American nationals against a foreign state by Senate-ratified treaty had been recognized as early as United States v. The Schooner Peggy, 5 U.S. (1 Cranch) 102 (1801) (Marshall, C.J.). The highly 
dark horse in the competing throng of asserted justifications was an obscure nineteenth century statute identified as the "Hostage Act." Though this statute played only an indirect role in the Supreme Court's dénouement of the legal drama, ${ }^{5}$ the government's sweeping claims concerning the powers delegated by the statute and the likelihood that these arguments will be repeated in future Iranian litigation ${ }^{7}$ call for a more leisurely examination of the Hostage Act's significance.

\section{BACKGROUND}

We turn first to a restatement of the legal aspects of the settlement of the hostage crisis. The agreement between the United States and Iran obligates this country to exclude from its courts a wide variety of cases against Iranian government entities, relegat-

controversial question of the compensability of settled claims under the takings clause of the fifth amendment, see Restatement (Second) of the Forkign RELations Law of thr UNITED STATES § 213 comment a (1965) (expressing no opinion), was regarded by most courts in the Iranian cases as not ripe for review. See Dames \& Moore, $101 \mathrm{~S}$. Ct. at 2991, and cases cited therein. But see Marschalk Co. v. Iran Nat'l Airlines Corp., 518 F. Supp. 69, 93-94 (S.D.N.Y.), certified questions answered, $101 \mathrm{~S}$. Ct. 3154, rev'd, 657 F.2d 3 (2d Cir. 1981).

4 Act of July 27, 1868, ch. $249, \S 3,15$ Stat. 223, 224 (codified at 22 U.S.C. $\S 1732$ (1976)). See Dames \& Moore v. Regan, 101 S. Ct. 2972, 2984-86 (1981).

- Dames \& Moore v. Regan, 101 S. Ct. 2972 (1981). The Court was "reluctant" to find "specific authorization" for presidential action in the statute, but viewed it and other provisions as "highly relevant in the looser sense of indicating Congressional acceptance of a broad scope for executive action" that "may be considered to "invite' "measures on independent presidential responsibility." " Id. at 2985-86 (quoting Youngstown Sheet \& Tube Co. v. Sawyer, 343 U.S. 579, 637 (1952) (Jackson, J., concurring)). See infra notes 26-33 and accompanying text.

- For example, in its brief in the Supreme Court, the United States argued that "[a]s a statute that is designed to be used in times of emergency, Section 1732 delegates to the President all powers that bear a 'reasonable relation to the particular emergency confronted'. . . . And because the statute relates to the conduct of foreign affairs, such a broad delegation of powers is permissible." Brief for Respondent at 52, Dames \& Moore (citation omitted) (emphasis added).

7 The July 19 deadline, discussed infra text accompanying note 9, necessitated expedited review of cases involving dissolution of restraints on Iranian assets. Issues not resolved by the Supreme Court's ruling and not mooted by the return of the assets remain open to consideration at a more normal pace. A renewed crush of litigation can also be expected when the fate of claims submitted for arbitration becomes clear. Litigants asserting the authority of the Hostage Act may find support in the narrow phrasing of the Supreme Court's rejection of the government's Hostage Act argument, see infra note 29, and in the earlier acceptance of that argument by two members of a District of Columbia Circuit panel, see American Int'l Group, Inc. v. Islamic Republic of Iran, 657 F.2d 430, 449-52 (D.C. Cir. 1981) (statement of McGowan, J., joined by Jameson, J.). One of the authors of this article was the third member of the panel, and expressed in brief form a contrary view. See id. at 45253 (statement of Mikva, J.). 
ing most of them to a special arbitral tribunal, and to free and return Iranian government assets that had been subjected to executive freeze orders and judicial attachments after the seizure of the hostages. ${ }^{8}$ The deadline for return of the funds held in American banks was July $19,1981 .^{\circ}$ The government filed pleadings in numerous cases across the country, requesting courts to dissolve attachments and preliminary injunctions and to suspend litigation on claims against Iran, ${ }^{10}$ as mandated by President Reagan's executive order and the regulations promulgated thereunder. ${ }^{11}$ The government also submitted a declaration by Secretary of State Alexander Haig cautioning that "[i]f the United States should be prevented from freeing the Iranian assets from judicial restraints ... the whole structure of the agreements may begin to crumble ... [with] serious consequences both for the claimants and for the foreign policy of the United States."12

The courts responded to this admonition by expediting proceedings in a variety of ways. The Second Circuit remanded an interlocutory appeal for reconsideration in light of changed circumstances, directing the District Court for the Southern District of New York to choose a representative case squarely presenting the crucial issues. ${ }^{13}$ When the district court found the President's actions unconstitutional in the chosen case, the Second Circuit certified questions to the Supreme Court. ${ }^{14}$ The First Circuit had al-

- See Declaration I, supra note 2, general principles A \& B; Declaration II, supra note 2, art. II; infra note 294. The freeze orders were issued under the authority granted by the International Emergency Economic Powers Act of 1978, 50 U.S.C. $\$ \$ 1701-1706$ (Supp. III 1979). See Dames \& Moore v. Regan, 101 S. Ct. 2972, 2982-84 (1981).

- See Declaration I, supra note 2, I 6.

${ }^{10}$ See, e.g., Statement of Interest of the United States, American Int'l Group, Inc. v. Islamic Republic of Iran, Nos. 80-1779, 80-1891 (D.C. Cir. filed Feb. 26, 1981).

${ }^{11}$ Exec. Order No. 12,294, 46 Fed. Reg. 14,111 (1981); Iranian Assets Control Regs., 31 C.F.R. 535 (1981).

12 See American Int'l Group, Inc. v. Islamic Republic of Iran, 657 F.2d 430, 436 (D.C. Cir. 1981); Statement of Interest of the United States, American Int'l Group, Inc. v. Islamic Republic of Iran, Nos. 80-1779, 80-1891, addendum (D.C. Cir. filed Feb. 26, 1981).

$1 s$ See New Eng. Merchants Nat'l Bank v. Iran Power Generation \& Transmission Co., 646 F.2d 779, 784-85 (2d Cir. Apr. 9, 1981).

${ }^{14}$ See Marschalk Co. v. Iran Nat'l Airlines Corp., 518 F. Supp. 69 (S.D.N.Y. June 11, 1981), certified questions answered, $101 \mathrm{~S}$. Ct. 3154 (July 2, 1981), rev'd, 657 F.2d 3 (2d Cir. July 10, 1981); cf. 28 U.S.C. $\$ 1254(3)$ (1976) (certification procedure). The Supreme Court ultimately took the unusual step of answering these questions, rather than letting its decision in Dames \& Moore speak for itself. See Iran Nat'l Airlines Corp. v. Marschalk Co., 101 S. Ct. 3154 (July 2, 1981); id. at 3155 (Powell, Marshall, \& Stevens, JJ., dissenting from answering of questions); cf. R. Stern \& E. Gressman, Supreme Court Practice § 9.2 (5th ed. 1978) (rarity of the certification procedure). 
ready remanded a case for reconsideration before President Reagan's ratification of President Carter's executive orders, ${ }^{16}$ and after a prompt initial determination by the District Court for the District of Massachusetts, ${ }^{16}$ it expedited a second appeal. ${ }^{17}$ The District of Columbia Circuit declined to remand and joined the First Circuit as one of the two courts of appeals to issue full opinions on the merits in time for Supreme Court review. ${ }^{18}$ Ultimately, however, the Court took a case for definitive resolution on a writ of certiorari to the Ninth Circuit before judgment there. ${ }^{19}$

The tensions of constitutional litigation were peculiarly evident in these cases. The usual reticence of courts in dealing with questions of foreign policy was reinforced by a series of explicit warnings from the executive branch that had begun even before the hostage settlement was negotiated. ${ }^{20}$ On the other hand, Amer-

16 Charles T. Main Int'l, Inc. v. Khuzestan Water \& Power Auth., 651 F.2d 800, 805 (1st Cir. May 22, 1981); Charles T. Main Int'l, Inc. v. Khuzestan Water \& Power Auth., No. 801027 (1st Cir. Feb. 23, 1981) (mem. \& order remanding case).

16 The district court modestly observed:

It takes no great amount of scholarship to realize that with several hundred cases pending against the government of Iran and other Iranian governmental, quasi-governmental and possibly private agencies, the final words resolving this question will come from the United States Supreme Court . . . . The need for such a ruling outweighs any purpose that might be served if this judge, who is but one of the more than twenty District Judges before whom these several hundred cases are pending, attempted to write the definitive constitutional exposition ....

Charles T. Main Int'l, Inc. v. United States, 509 F. Supp. 1162, 1164 (D. Mass. Mar. 17, 1981), aff'd sub nom. Charles T. Main Int'l, Inc. v. Khuzestan Water \& Power Auth., 651 F.2d 800 (1st Cir. May 22, 1981).

${ }^{17}$ Charles T. Main Int'1, Inc. v. Khuzestan Water \& Power Auth., 651 F.2d 800 (1st Cir. May 22, 1981).

18 American Int'l Group, Inc. v. Islamic Republic of Iran, 657 F.2d 430, 437 (D.C. Cir. June 5, 1981).

19 Dames \& Moore v. Regan, 452 U.S. 932 (June 11, 1981) (granting certiorari). The losing parties in the First Circuit and the District of Columbia Circuit had not filed petitions for certiorari, and the Supreme Court does not grant certiorari to a prevailing party seeking review of a court of appeals decision. See R. STERn \& E. Gressman, supra note 14, \& 2.4; cf. Perez v. Ledesma, 401 U.S. 82, 87 n.3 (1971) (prevailing party has no standing to appeal). But cf. United States v. Nixon, 418 U.S. 683, 686 \& n.1 (1974) (granting certiorari before judgment at instance of prevailing party in the district court). Justice Rehnquist dissented from the grant of the writ in Dames \& Moore, 452 U.S. at 933. Certiorari before judgment has not been uncommon in cases of unusual public importance. See, e.g., United States v. Nixon, 418 U.S. 683 (1974); Bolling v. Sharpe, 347 U.S. 497 (1954); Youngstown Sheet \& Tube Co. v. Sawyer, 343 U.S. 579 (1952).

${ }^{20}$ In the summer of 1980, the government had filed Suggestions of Interest in hundreds of pending cases, requesting that all further proceedings in litigation against Iranian entities be stayed. In the District of Columbia Circuit, the government's Suggestion and accompanying brief urged the court to exercise its inherent power to stay proceedings on appeal indefinitely, with an opportunity for reconsideration in 90 days. Brief for the United States as 
ican corporate litigants urged that private property was being unlawfully seized to redeem the Carter administration's failures. The government identified a number of tenuous statutory bases for its actions, which offered a tempting opportunity for the courts to uphold this extenuated exercise of executive power without entrenching it as a constitutional prerogative and further aggrandizing the role of the President at the expense of Congress. ${ }^{21}$

Writing for a unanimous Court on most aspects of the case, ${ }^{22}$ Justice Rehnquist stressed in Dames \& Moore v. Regan "that the expeditious treatment of the issues involved by all of the courts which have considered the President's actions makes us acutely aware of the necessity to rest decision on the narrowest possible ground capable of deciding the case." 23 He described Justice Jackson's well-known classification of executive actions according to

Amicus Curiae, American Int'l Group, Inc. v. Islamic Republic of Iran, Nos. 80-1779 \& 801891 (D.C. Cir. filed Sept. 26, 1980). The request was accompanied by an affidavit of Treasury Secretary William Miller, warning that any judicial action on the merits could produce "unintended signals which the Iranians might construe as representing the policy or position of the U.S. Government," intimating that the government would prefer not to be obliged to advocate the sovereign immunity of Iran at the moment and pointing out that court judgments could complicate eventual solution of the "claims problem," which was "inextricably linked to the overall crisis." Id., app. The government also offered to submit a classified affidavit from Deputy Secretary of State Warren Christopher for ex parte inspection in camera; the District of Columbia Circuit declined this offer, but some other courts accepted. See, e.g., In re Related Iranian Cases, No. C-79-3542 RFP (N.D. Cal. Nov. 13, 1980) (order granting 90-day stay in 20 cases after viewing affidavits of Deputy Secretary Christopher and Secretary of State Edmund Muskie). Both the District of Columbia Circuit and the First Circuit ordered renewable 90-day stays, American Int'l Group, Inc. v. Islamic Republic of Iran, Nos. 80-1779 \& 80-1891 (D.C. Cir. filed Sept. 26, 1980) (order); Charles T. Main Int'l, Inc. v. Khuzestan Water \& Power Auth., No. 80-1027 (1st Cir. Oct. 30, 1980) (order); New Eng. Merchants Nat'l Bank v. Iran Power Generation \& Transmission Co., No. 80-1071 (1st Cir. Oct. 30, 1980) (order), as did numerous district courts. Some district courts denied stays, however. E.g., New Eng. Merchants Nat'l Bank v. Iran Power Generation \& Transmission Co., 502 F. Supp. 120, 133-34 (S.D.N.Y. 1980) (96 consolidated cases). The District of Columbia Circuit's stay was extended, American Int'l Group, Inc. (D.C. Cir. filed Dec. 24, 1980) (order), after the filing of further affidavits, including a public affidavit of Deputy Secretary Christopher warning that a court judgment could jeopardize ongoing negotiations in Algeria for release of the hostages. Supplemental Brief for the United States Amicus Curiae, American Int'l Group, Inc., app. 1.

21 See infra note 28.

22 Justice Stevens considered it unnecessary to decide whether the Court of Claims would have jurisdiction to hear takings claims based on the President's agreement with Iran, Dames \& Moore, $101 \mathrm{~S}$. Ct. at 2992 (Stevens, J., concurring), and Justice Powell dissented from the holding that no compensation was required for the nullification of attachments, preferring to leave that question for resolution in the Court of Claims, id. at 2992-93 (Powell, J., concurring in part and dissenting in part).

${ }^{23}$ Id. at 2977. 
their degree of concordance with the expressed will of Congress 24 as "analytically useful," adding that the complexity of political phenomena was better captured by the metaphor of a spectrum than by a set of neat pigeonholes. ${ }^{25}$

Laying aside these general considerations for the moment, the Court sought to find a statutory solution to the controversy before it. $^{28}$ It agreed with the lower courts that the President's freeze and subsequent release were explicitly authorized by the International Emergency Economic Powers Act, ${ }^{27}$ but declined to stretch the Act's language to cover the suspension of claims. ${ }^{28}$ The Court also

24 Youngstown Sheet \& Tube Co. v. Sawyer, 343 U.S. 579, 635-38 (1952) (Jackson, J., concurring).

${ }^{25} 101 \mathrm{~S}$. Ct. at 2981-82. Justice Jackson's analysis had provided the framework for inquiry in many lower court decisions in the Iranian cases, see, e.g., American Int'l Group, Inc. v. Islamic Republic of Iran, 657 F.2d 430, 439 (D.C. Cir. 1981); Charles T. Main Int'l, Inc. v. Khuzestan Water \& Power Auth., 651 F.2d 800, 805 (1st Cir. 1981); Marschalk Co. v. Iran Nat'l Airlines Corp., 518 F. Supp. 69, 77 (S.D.N.Y.), certified questions answered, 101 S. Ct. 3154, rev'd, 657 F.2d 3 (2d Cir. 1981), but Justice Rehnquist's opinion did not wholeheartedly embrace it as doctrine, see, e.g., $101 \mathrm{~S}$. Ct. at 2978 ("both parties agree [Jackson's opinion] brings together as much combination of analysis and common sense as there is in this area"); id. at 2981 ("The parties and the lower courts . . . have all agreed that much relevant analysis is contained" in the Youngstown opinions). Justice Rehnquist's nebulous language was undoubtedly intended to be consistent with his promise "to lay down no general "guide-lines," "and with his observation that "the decisions of the Court in this area have been rare, episodic, and afford little precedential value for subsequent cases," id. at 2977-78.

26 Most of the opinions in the Iranian cases did not take the time to distinguish between the relevance of the statutory authorization issue as a nonconstitutional ground of decision that would enable the courts to avoid premature decision of a constitutional question, see Ashwander v. TVA, 297 U.S. 288, 346-47 (1936) (Brandeis, J., concurring), and its relevance as an element of separation-of-powers analysis. The structure of these opinions probably reflects the courts' ultimate conclusion that no easy statutory answer was available for the claims suspension question.

${ }_{27} 50$ U.S.C. $\S 1701-1706$ (Supp. III 1979); see Dames \& Moore, 101 S. Ct. at 2982-84. The statute was a modification of the Trading with the Enemy Act, 50 U.S.C. app. $\$$ 5(b) (1976), which had prompted litigation of considerable relevance to the Iranian cases in the postwar period. See Orvis v. Brownell, 345 U.S. 183 (1953); Zittman v. McGrath, 341 U.S. 446 (1951).

2s $101 \mathrm{~S}$. Ct. at 2984. Judge Breyer, concurring in the First Circuit decision, had argued that a holding on inherent presidential power could be avoided if civil lawsuits were considered "the 'exercising' of a 'right' with respect to 'property" " within the meaning of the International Emergency Economic Powers Act, 50 U.S.C. \& 1702(a)(1)(B) (Supp. III 1979). Charles T. Main Int'l, Inc. v. Khuzestan Water \& Power Auth., 651 F.2d 800, 816 (1st Cir. 1981) (Breyer, J., concurring). The First Circuit majority openly admitted the appeal of a statutory solution, but could not accept this interpretation of the wording. Id. at $809 \mathrm{n} .13$ ("The very breadth of the powers given the President under IEEPA, and the desirability of relying on statutory rather than constitutional authority, might tempt one to find an implied congressional grant of authority. Nevertheless we feel uneasy in resting on such a construction."). 
concluded that the Hostage Act failed to provide an express delegation of power to suspend claims. ${ }^{29}$ It viewed both statutes, however, as "highly relevant in the looser sense of indicating congressional acceptance of a broad scope for executive action in circumstances such as those presented in this case." Combining this evidence with the long history of congressional acquiescence in the settlement of claims against foreign states by executive agreement, ${ }^{31}$ and with Congress's failure to express displeasure with the Iranian agreement, ${ }^{32}$ the Court concluded that the President had

29 The Court stated:

Although the broad language of the Hostage Act suggests it may cover this case, there are several difficulties with such a view. The legislative history indicates that the Act was passed in response to a situation unlike the recent Iranian crisis. Congress in 1868 was concerned with the activity of certain countries refusing to recognize the citizenship of naturalized Americans traveling abroad, and repatriating such citizens against their will .... These countries were not interested in returning the citizens in exchange for any sort of ransom. This also explains the reference in the Act to imprisonment "in violation of the rights of American citizenship." Although the Iranian hostage-taking violated international law and common decency, the hostages were not seized out of any refusal to recognize their American citizenship-they were seized precisely because of their American citizenship. The legislative history is also somewhat ambiguous on the question whether Congress contemplated presidential action such as that involved here or rather simply reprisals directed against the offending foreign country and its citizens.

$101 \mathrm{~S}$. Ct. at 2985 (citations omitted) (emphasis in original).

so Id. The Court continued:

IEEPA delegates broad authority to the President to act in times of national emergency with respect to property of a foreign country. The Hostage Act similarly indicates congressional willingness that the President have broad discretion when responding to the hostile acts of foreign sovereigns. As Senator Williams, draftsman of the language eventually enacted as the Hostage Act, put it:

"If you propose any remedy at all, you must invest the executive with some discretion, so that he may apply the remedy to a case as it may arise. As to England or France he might adopt one policy to relieve a citizen imprisoned by either one of those countries; as to the Barbary powers, he might adopt another policy; as to the islands of the ocean another. With different systems of government he might adopt different means."

Proponents of the bill recognized that it placed "a loose discretion" in the President's hands, ... (Senator Stewart), but argued that "[s]omething must be intrusted to the Executive" and that "[t]he President ought to have the power to do what the exigencies of the case require to rescue [a] citizen from imprisonment." . . (Senator Williams). An original version of the Act, which authorized the President to suspend trade with a foreign country and even arrest citizens of that country in the United States in retaliation, was rejected because "there may be a great variety of cases arising where other and different means would be equally effective and where the end desired could be accomplished without resorting to such dangerous and violent measures." . . . (Sen. Williams).

Id. at 2985-86 (citations omitted).

s1 The Court described this element as "[c]rucial to our decision today." Id. at 2987.

${ }^{32}$ See id. at 2991 \& n.13. 
the power to settle claims against Iran as "a necessary incident to the resolution of a major foreign policy dispute" between the two countries. ${ }^{33}$

Thus the Hostage Act, derided by one court as a deus ex machina, ${ }^{34}$ has been pushed back into the wings for the present. The Supreme Court has stated that the Act's authorization of presidential action does not encompass the suspension of claims against Iran, ${ }^{35}$ though it is unclear whether this is because the Iranian crisis did not come within the scope of the Act or because the settlement of claims exceeds the powers delegated. Given this ambiguity, and because of the potentially vast scope of the statute, it seems advisable to take advantage of the current lull in the Iranian litigation and to pursue a more leisurely nonjudicial inquiry into the origins and significance of the so-called Hostage Act. Furthermore, observing the creation, submergence, and resuscitation of an obscure statute sheds some useful light on the lawmaking process as a whole.

\section{The Statute}

The protagonist of this article is the statutory provision presently found in title 22 of the United States Code at section 1732. Though it has recently appeared in briefs and decisions as the "Hostage Act," an inspection of the usual indices of popular names and a search of American case law up to the time of the storming of the American embassy in Tehran do not reveal any mention of that name. "Section 1732" is as good and functional a name as any for present purposes.

ss Id. at 2991. The Court did not decide the compensability of any taking that might result from the suspension of claims, an issue both sides conceded was unripe, but did hold that jurisdiction would be available in the Court of Claims to resolve this issue and to provide a remedy later. Id. at 2991-92.

${ }^{34}$ Marschalk Co. v. Iran Nat'l Airlines Corp., 518 F. Supp. 69, 84 n.18 (S.D.N.Y), certified questions answered, 101 S. Ct. 3154, rev'd, 657 F.2d 3 (2d Cir. 1981).

${ }^{35} 101 \mathrm{~S}$. Ct. at 2985; see supra note 29.

36 See, e.g., Dames \& Moore, $101 \mathrm{~S}$. Ct. at 2985; American Int'l Group, Inc. v. Islamic Republic of Iran, 657 F.2d 430, 449 (D.C. Cir. 1981) (statement of McGowan, J.). But see Exec. Order No. 12,294, 46 Fed. Reg. 14,111 (1981) (just "Section 1732 of Title 22"); Exec. Orders Nos. 12,276-12,284, 46 Fed. Reg. 7913-30 (1981) (same).

${ }^{37}$ As Justice Rehnquist pointed out in Dames \& Moore, the Court's decision was based on the language and history of the statute and not on any "short-hand description." $101 \mathrm{~S}$. Ct. at 2984 n.7 (quoting W. Shakespeare, Romeo aND JuLIET, act II, scene ii, l.43-"What's in a name?"). Nonetheless, it is important to bear in mind that the Hostage Act applies to situations far more common than hostage-takings, lest an overly broad interpretation of the powers it confers be rationalized by the false impression that they will rarely be exercised. 
Because section 1732 is not a widely known statute, and because it has not yet amassed the quantity of judicial gloss that could render it superfluous, this investigation would do well to heed the elementary principles of statutory construction ${ }^{38}$ and begin with its language:

Whenever it is made known to the President that any citizen of the United States has been unjustly deprived of his liberty by or under the authority of any foreign government, it shall be the duty of the President forthwith to demand of that government the reasons of such imprisonment; and if it appears to be wrongful and in violation of the rights of American citizenship, the President shall forthwith demand the release of such citizen, and if the release so demanded is unreasonably delayed or refused, the President shall use such means, not amounting to acts of war, as he may think necessary and proper to obtain or effectuate the release; and all the facts and proceedings relative thereto shall as soon as practicable be communicated by the President to Congress. ${ }^{39}$

This language on first glance prompts a few simple observations, but the wording seems calculated to raise more questions than it answers. On the positive side, it can be seen that the statute applies as a threshold matter when a citizen is known to be "unjustly deprived of his liberty"; the language later suggests that liberty is to be construed narrowly as liberty of movement, ${ }^{40}$ and that the deprivation must be an "imprisonment" rectifiable by a "release."

ss "The starting point in every case involving construction of a statute is the language itself." Blue Chip Stamps v. Manor Drug Stores, 421 U.S. 723, 756 (1975) (Powell, J., concurring).

30 22 U.S.C. $\$ 1732$ (1976). This language differs slightly from the wording in the Statutes at Large, which is controlling, see Stephan v. United States, 319 U.S. 423, 426 (1943). The latter reads:

Whenever it shall be made known to the President that any citizen of the United States has been unjustly deprived of his liberty by or under the authority of any foreign government, it shall be the duty of the President forthwith to demand of that government the reasons for such imprisonment, and if it appears to be wrongful and in violation of the rights of American citizenship, the President shall forthwith demand the release of such citizen, and if the release so demanded is unreasonably delayed or refused, it shall be the duty of the President to use such means, not amounting to acts of war, as he may think necessary and proper to obtain or effectuate such release, and all the facts and proceedings relative thereto shall as soon as practicable be communicated by the President to Congress.

Act of July 27, 1868, ch. 249, § 3, 15 Stat. 223, 224 (emphasis added).

to Cf. R. Berger, Government By Judiciary 269-70 (1977) (arguing that "liberty" in the fourteenth amendment means freedom from physical restraint). 
The President's duty to demand reasons arises from any unjust imprisonment, but his further duties, to demand release and to use means to effectuate release (and then to report to Congress), only persist if the imprisonment turns out to appear "wrongful and in violation of the rights of American citizenship." There is no mention of hostages, ransom, extortion, or terrorism.

What section 1732 means by "rights of American citizenship" is far from clear on a first reading. This statute was enacted in 1868 , and the meaning attributed in that period to phrases like "privileges or immunities of citizens of the United States" has long been a subject of controversy." What "wrongful" and "unjustly" mean, and how they differ, is also uncertain. Nor is it immediately apparent whether the statute merely imposes a duty on the President or also grants him powers with which to fulfill that duty. Finally, there is a question crucial for the Iranian cases: what are the permissible "means not amounting to acts of war" that the President is expected to use?

Examination of section 1732's context in the United States Code suggests that its references to citizenship have a technical significance. The section is included in chapter 23 of title 22, entitled "Protection of Citizens Abroad," and the only other provision in that chapter is section 1731 . The Code points out that sections 1731 and 1732 were originally sections 2 and 3 of an 1868 statute, entitled "An Act concerning the Rights of American Citizens in foreign States." 2 Section 1731 reads: "All naturalized citizens of the United States while in foreign countries are entitled to and shall receive from this Government the same protection of persons and property which is accorded to native-born citizens." 43 The juxtaposition of these provisions suggests that the present section 1732 was intended to enforce section 1731 by making an explicit statement of the kind of "protection" persons could expect in a particularly threatening circumstance-wrongful imprisonment by a foreign power. The rest of the 1868 Act consisted of a preamble and a declaratory first section, both stressing the right of expatriation, that were incorporated into the revised statutes, but that

41 See, e.g., J. Ely, Democracy and Distrust 22-30 (1980).

12 Act of July 27, 1868, ch. 249, 15 Stat. 223.

43 22 U.S.C. \& 1731 (1976). Again, the original language, which has the force of law, differs slightly: "That all naturalized citizens of the United States, while in foreign states, shall be entitled to, and shall receive from this government, the same protection of persons and property that is accorded to native-born citizens in like situations and circumstances." Act of July 27, 1868, ch. 249, § 2, 15 Stat. 223, 224 (emphasis added). 
have slipped out of the current code."4 Although these legislative siblings shed little light on some of the questions raised by section 1732 , they strongly indicate that the phrase "violation of the rights of American citizenship" has a key role in determining the section's scope. ${ }^{45}$ Taking our cue from this observation, we shall henceforth refer to the 1868 statute by a shortened form of its original title, calling it the "Citizens in Foreign States Act."

The history of the Citizens in Foreign States Act in the courts is almost entirely unilluminating with regard to section 1732 in general and the phrase "means not amounting to acts of war" in particular. Most frequently, the Act has been cited for the purpose stated in its preamble, to demonstrate that the United States believes that a country's citizens may expatriate themselves. ${ }^{46}$ One

\section{"These provide:}

WhEREAs the right of expatriation is a natural and inherent right of all people, indispensable to the enjoyment of the rights of life, liberty, and the pursuit of happiness; and whereas in the recognition of this principle this government has freely received emigrants from all nations, and invested them with the rights of citizenship; and whereas it is claimed that such American citizens, with their descendants, are subjects of foreign states, owing allegiance to the governments thereof; and whereas it is necessary to the maintenance of public peace that this claim of foreign allegiance should be promptly and finally disavowed: Therefore,

Be it enacted . . . , That any declaration, instruction, opinion, order, or decision of any officers of this government which denies, restricts, impairs, or questions the right of expatriation, is hereby declared inconsistent with the fundamental principles of this government.

Sections 1 (including the preamble), 2, and 3 of the 1868 Act were codified as sections 1999, 2000 , and 2001, respectively, in the Revised Statutes. The disappearance of the preamble and the first section of the act from the Code do not lessen their significance for interpretation of the still-codified third section, for they have never been repealed, and it is the legislative intent behind the original Act that is determinative absent a clear expression of a congressional intention to change the scope of the statute when codifying it. See Muniz v. Hoffman, 422 U.S. 454, 467-74 (1975).

45 To anticipate a little, the legislative history compels a broad interpretation of this phrase, roughly expressible as "violations of the rights due to American citizens under international law, treaties, and the laws of the foreign state (but not the laws of the United States)." See infra text accompanying notes 253-54. Justice Rehnquist expressed doubt whether the seizure of American diplomats in Iran came within the scope of the statute, see Dames \& Moore, $101 \mathrm{~S}$. Ct. at 2985 , but the analysis pursued here suggests that it did. See infra text accompanying notes 288-90.

16 See Perkins v. Elg, 307 U.S. 325, 334 (1939) (expatriation must be voluntary); Weedin v. Chin Bow, 274 U.S. 657, $671-72$ (1927); United States v. Wong Kim Ark, 169 U.S. 649, 713 (1898) (Fuller, C.J., dissenting); Fong Yue Ting v. United States, 149 U.S. 698, 71516 (1893) (actually mentioning third section, though in passing); Dos Reis ex rel. Camara v. Nicollo, 161 F.2d 860, 862 (1st Cir. 1947); Bauer v. Clark, 161 F.2d 397, 404 (7th Cir.), cert. denied, 332 U.S. 839 (1947); Meyer v. United States, 141 F.2d 825, 826 (5th Cir. 1944); Schneider v. Rusk, 218 F. Supp. 302, 306 (D.D.C. 1963) (three-judge court), rev'd, 377 U.S. 163 (1964) (no Justice mentioned statute); Podea v. Marshall, 83 F. Supp. 216, 220 
such case, although deciding only a question of diversity jurisdiction, observed in passing that "the act itself, as does its title, deals only with the protection of aliens by birth who have become citizens by naturalization."

The third section of the Citizens in Foreign States Act finally began to attract some attention in the 1950's, though without producing any holdings. In Johnson $v$. Eisentrager, ${ }^{48}$ the Supreme Court denied recourse to habeas corpus to enemy aliens held by United States military forces abroad. The Court noted that citizenship entails some privileges refused to aliens, mentioning as an illustration section 1732 , which by its terms only extends protection to citizens. ${ }^{49}$ But this neglected statute truly began to come into its own in a series of cases where the government proffered the President's responsibility under section 1732 to protect citizens who get into trouble abroad as one of several justifications for denying them the right to get there in the first place. After some mixed success, ${ }^{50}$ this argument became one of the underpinnings of the Supreme Court's decision in Zemel $v$. Rusk, ${ }^{51}$ upholding a ban on travel to Cuba. None of these cases, however, relied on section 1732 as a source of executive authority to restrict travel. ${ }^{.2}$

(E.D.N.Y. 1949), rev'd, 179 F.2d 306 (2d Cir. 1950); United States ex rel. Cicco v. Longo, 46 F. Supp. 170, 174 (D. Conn. 1942); Schaufus v. Attorney Gen., 45 F. Supp. 61,66 (D. Md. 1942); In re Sproule, 19 F. Supp. 995, 998 (S.D. Cal. 1937); Ex parte Hing, 22 F.2d 554, 556 (W.D. Wash. 1927); Ex parte Gilroy, 257 F. 110, 117 (S.D.N.Y. 1919); Comitis v. Parkerson, 56 F. 556, 559 (C.C.E.D. La. 1893), appeal dismissed, 163 U.S. 681 (1896); In re Look Tin Sing, 21 F. 905, 907-08 (C.C.D. Cal. 1884).

17 Comitis v. Parkerson, 56 F. 556, 559 (C.C.E.D. La. 1893) (dictum), appeal dismissed, 163 U.S. 681 (1896). The court held that one of the parties was a citizen of Louisiana and not an alien, so that diversity jurisdiction did not exist. The court's dictum is clearly refuted by the legislative history, See infra text accompanying notes 225-27.

18339 U.S. 763 (1950).

19 Id. at 770.

so See Worthy v. Herter, 270 F.2d 905, 910 (D.C. Cir.) (upholding travel ban), cert. denied, 361 U.S. 918 (1959); Briehl v. Dulles, 248 F.2d 561, 568 (D.C. Cir. 1957) (en banc) (denial of passport to communist), rev'd sub nom. Kent v. Dulles, 357 U.S. 116 (1958); Schachtman v. Dulles, 225 F.2d 938, 942 (D.C. Cir. 1955) (reversing denial of passport); MacEwan v. Rusk, 228 F. Supp. 306, 308 (E.D. Pa. 1964) (upholding travel ban), aff'd, 344 F.2d 963 (3d Cir. 1965); Zemel v. Rusk, 228 F. Supp. 65, 70-71 (D. Conn. 1964) (three-judge court) (same), aff'd, 381 U.S. 1 (1965).

-1 381 U.S. 1, 15 (1965). The Court observed that "travel to Cuba by American citizens might involve the Nation in dangerous international incidents," particularly in view of the President's obligations under the Act.

s1 In Worthy v. Herter, 270 F.2d 905 (D.C. Cir.), cert. denied, 361 U.S. 918 (1959), the court characterized the kinds of actions section 1732 would encompass as the persuasive or compulsory use of diplomatic instrumentalities:

The assistance the Congress requires the President to afford an American citizen in 
Finally, a pair of cases in the 1970's discussed the Citizens in Foreign States Act in the context of Americans actually imprisoned abroad. In Holmes v. Laird, ${ }^{\text {ss }}$ the Court of Appeals for the District of Columbia Circuit, in holding that it could not enjoin surrender of United States soldiers to West German authorities for trial, refused to determine whether the soldiers' sentences unjustly deprived them of liberty; it cited section 1732 as a direction to the plaintiffs to seek relief from the executive branch. ${ }^{.4}$ And in Redpath $v$. Kissinger, ${ }^{55}$ where the plaintiff sought to compel the State Department to rescue him from a Mexican jail, the District Court for the Western District of Texas concluded that the President's responsibilities under section 1732 were "clearly of a diplomatic nature involving the exercise of discretion by the Executive, or under his direction," and not a proper subject for mandamus..$^{56}$

As of 1979, then, no court had ever held that the third section of the Citizens in Foreign States Act empowered the President to perform any act whatsoever. The conditions for its application had never been explored, and the scope of the President's authority had never been delineated. The only firm statement that could be made about section 1732 was that courts would be reluctant to enforce any duties it imposed on the President. ${ }^{57}$

Into this legal vacuum stepped the Ayatollah Khomeini. The Iranian government's ratification of the seizure of the American embassy and its personnel by certain "students" provoked a series of American responses that included a crackdown on violations of immigration rules by Iranian students present in this country. ${ }^{88}$ The United States District Court for the District of Columbia held the regulation implementing the new enforcement policy to be unauthorized by the immigration laws and a denial of equal protection. ${ }^{59}$ The court rejected any suggestion that section 1732 vali-

trouble abroad is a phase of "foreign affairs". The instrumentalities he must use to fulfill the congressional mandate are diplomatic, or foreign-service consular. A decision on the part of the President to prevent, if possible, the necessity for calling into play his diplomatic instrumentalities and the use of his powers-persuasive or compulsory-upon a foreign nation is a phase of "foreign affairs".

Id. at 910 (footnote omitted).

ss 459 F.2d 1211 (D.C. Cir.), cert. denied, 409 U.S. 869 (1972).

54 Id. at 1225 \& n.108.

ss 415 F. Supp. 566 (W.D. Tex.), aff'd mem., 545 F.2d 167 (5th Cir. 1976).

BB Id. at 568-69.

${ }^{67}$ See infra note 256.

B8 See Narenji v. Civiletti, 617 F.2d 745 (D.C. Cir.), cert. denied, 446 U.S. 957 (1980).

s9 Narenji v. Civiletti, 481 F. Supp. 1132, 1140-41, 1144 (D.D.C. 1979), rev'd, 617 F.2d 
dated the regulation, noting that, regardless of its exact scope, the section did not affect the fifth amendment issue: "while it may give the President some extra latitude to deal militarily or economically with a foreign nation holding American citizens, it does not act to authorize the Chief Executive to abrogate individual rights guaranteed by the Constitution." ${ }^{100}$ On appeal, the district court's statutory and constitutional rulings were reversed, but section 1732 played no role except in a statement by one of the original panel members accompanying a per curiam order denying rehearing en banc. ${ }^{\text {B1 }}$

The next appearance of section 1732 was in a familiar context, the executive power over passports. ${ }^{62}$ The United States had revoked the passport of Phillip Agee, a former agent of the Central Intelligence Agency living in Europe, whose efforts against the CIA had concededly been damaging to American intelligence activities. ${ }^{63}$ In an opinion holding that the Secretary of State lacked statutory authorization to revoke Agee's passport, the district court stated that its decision would not foreclose actions "to limit Agee's travel by other means," observing that "[i]f his activities are detrimental to the hostages in Iran, a special statute exists, 22 U.S.C. \& 1732 (1976), which appears to give the President extraordinary authority to act." ${ }^{\circ 4}$ On appeal, a divided panel of the District of Columbia Circuit affirmed, the majority noting that section 1732 was "not germane to this case" because the government had "made no mention whatsoever of the Iranian crisis" in revoking Agee's passport. ${ }^{85}$ The dissenting judge, however, in the first reported judicial opinion to refer to section 1732 as a "hostage" statute, found that the provision "fit[] the present situation in Iran like a glove and, as in Zemel, support[ed] the Secretary's denial (or

745 (D.C. Cir.), cert. denied, 446 U.S. 957 (1980).

${ }^{\circ}$ Id. at 1141 n.7.

-2 In the situation with which we are here dealing, the President's power is at its zenith-right up to the brink of war and he does act pursuant to the 'express authorization' of Congress. . . . This direction to the President by Congress is unequivocal. It completely supports every act and order that he has taken to free the United States hostages. No further scrutiny of his acts is required or necessary.

Narenji v. Civiletti, 617 F.2d 745, 753 (D.C. Cir.) (MacKinnon, J.), cert. denied, 446 U.S. 957 (1980).

62 See supra notes 50-52 and accompanying text.

ss See Haig v. Agee, 101 S. Ct. 2766, 2769-71 (1981).

- Agee v. Vance, 483 F. Supp. 729, 732 (D.D.C.), aff'd sub nom. Agee v. Muskie, 629 F.2d 80 (D.C. Cir. 1980), rev'd sub nom. Haig v. Agee, 101 S. Ct. 2766 (1981).

6s Agee v. Muskie, 629 F.2d 80, 84 n.3 (D.C. Cir. 1980), rev'd sub nom. Haig v. Agee, 101 S. Ct. 2766 (1981). 
revocation) of a passport." pret the statutory language "such means, not amounting to acts of war, as [the President] may think necessary and proper to obtain or effectuate the release," apparently regarding it as self-evident that any rational connection between Agee's activities and the hostages would justify applying the statute to his passport as "necessary and proper." ${ }^{67}$ Ultimately, the Supreme Court reversed the circuit court's decision, though it made no allusion to section $1732 ;^{68}$ the Court found sufficient authority for passport revocation in the passport statutes and traditional executive practices, a conclusion several Justices regarded as a partial repudiation of the Court's earlier analysis in Kent $v$. Dulles. ${ }^{69}$

Thus, on the eve of the Iranian asset litigation, section 1732 had played a role in several judicial opinions, but no court had yet had occasion to ascertain the intended scope of the President's duties and powers under the statute or to resolve a controversy turning on construction of its language. In 112 years, no court had examined this nineteenth century enactment in a situation testing the limits of its wording or requiring a determination of the legislative intent behind its awkward and obscure phraseology. This century of dormancy may be the most eloquent evidence of the intended breadth of the statute. As it turns out, however, the Citizens in Foreign States Act also possesses a rich and fascinating legislative history, one that accounts for many of the Act's peculiarities, although it does not provide easy solutions to every ambiguity in the statutory language.

\section{The Citizens in Foreign States Act in the Light of Its LEgisLative History}

The Citizens in Foreign States Act of 1868 was passed in reaction to a foreign policy crisis no less notorious in its day than the Iranian crisis has been in ours. After a brief introduction to the issues and personalities that fueled the public debate, this part will rehearse at some length the stages that led to the enactment of the statute and the addition of the strangely worded section 1732 as a

${ }^{68}$ Id. at 96 (MacKinnon, J., dissenting). The reference is to Zemel v. Rusk, 381 U.S. 1 (1965); see supra text accompanying note 51 .

${ }^{67} 629$ F.2d at 97 (Mackinnon, J., dissenting).

${ }^{68}$ Haig v. Agee, 101 S. Ct. 2766 (1981); see id. at 2772 n.14.

${ }^{69} 357$ U.S. 116 (1958); see Haig v. Agee, 101 S. Ct. at 2783 (Blackmun, J., concurring); id. at 2784 (Brennan and Marshall, JJ., dissenting). 
Senate floor amendment. An attempt to summarize the lessons of the legislative history follows, and the final section of this part sets out an interpretation of the statute based on these conclusions.

\section{A. Historical Background}

American public opinion was quite hostile to Great Britain in the early Reconstruction period. British support for the Confederacy had exacerbated traditional grudges against the former mother country; officially, Great Britain had remained neutral during our Civil War, but her neutrality laws were much weaker than our own, and the South had enjoyed considerable British sympathy and support. ${ }^{70}$ This enmity was kept alive by outstanding claims against the British government, most notably claims for damage inflicted on Northern merchant shipping by the Confederate privateer Alabama, which had been built and fitted out in Liverpool. ${ }^{71}$

These tensions were further increased by American sympathy for victims of British repression in Ireland. Irish revolutionary groups, most notably the Fenian Brotherhood, ${ }^{72}$ welcomed the Anglo-American chill as an opportunity to gain the United States as an ally in their national cause. Fenians in Ireland relied heavily on American Fenians, whose greater prosperity and Civil War combat service provided arms and military experience. ${ }^{73}$ Many Irish-Americans enthusiastically devoted their energies to the cause, and the activities of these American Fenians became for several years a decisive factor in Anglo-American relations, particularly when the Fenians tried to precipitate war between the United States and Great Britain.

The first major project of the American Fenians was to invade Canada. They expected the United States government to connive

7o See, e.g., C. Campbell, From Revolution to Rapprochement 95-113 (1974); B. Jenkins, Fenians and Anglo-American Relations During Reconstruction 181 (1969); Cong. Globe, 39th Cong., 1st Sess. 4195-96 (1866) (remarks of Rep. Banks and Rep. Orth) (analyzing British and American neutrality law).

71 See C. Campbell, supra note 70, at 102-03, 111-13; 1 Encyclopedia of American Foreign Policy 35-36 (A. De Conde ed. 1978); 3 id. at 950-51.

72 See generally W. D'ARcy, The Fenian Movement in the United States: 1858-1886 (1947); B. Jenkins, supra note 70; L. O'Broin, Fenian Fever (1971); C. Tansill, America AND THE FIGHT POR IRISH FREEdom: 1866-1922 (1957). The Brotherhood was founded in New York by John O'Mahoney, and in Dublin on St. Patrick's Day, 1858, by James Stephens. L. O'BroIN, supra, at 1-3. It was also known, inter alia, as the Irish Revolutionary Brotherhood or Irish Republican Brotherhood. Id. at 1.

73 See L. O'BrolN, supra note 72, at 6 . Arms and experience were also expected from Fenian converts in the British army. Id. 
in this effort, ${ }^{74}$ but British and American forces blocked a Fenian expedition against Campobello Island in April 1866. ${ }^{75}$ Seven weeks later, 1500 Fenians made a surprise attack across the Niagara River, and they were repelled by the Canadians only after a minor battle. ${ }^{76}$ President Johnson issued a proclamation warning against such raids ${ }^{77}$ and had the leaders arrested for violating American neutrality laws. ${ }^{78}$ In response, the House of Representatives passed both a resolution requesting that the prosecutions be dropped ${ }^{79}$ and a bill to weaken the neutrality laws. ${ }^{80}$ Meanwhile, the Canadians had also taken prisoners, including the sympathetic figure of a Catholic priest, Father John McMahon, who was sentenced to death in October $1866 .^{81}$

The assault on Canada was at best an indirect way of achieving independence for Ireland, but a more promising opportunity

74 W. D'ARcy, supra note 72, at 84-85; L. O'BroIN, supra note 72 , at 52,67 .

${ }^{75} \mathrm{~L}$. O'BRorn, supra note 72 , at $62-63$.

${ }^{76} \mathrm{~W}$. D'ARcY, supra note 72, at 137-39; L. O'BrolN, supra note 72, at 66-68.

77 The proclamation observed that "certain evil-disposed persons, within the jurisdiction of the United States," had set on foot a "military expedition and enterprise" against British North America in violation of United States law and the law of nations, "admonish[ed] and warn[ed] all good citizens of the United States against taking part in or in anywise aiding, countenancing, or abetting" the expedition, and authorized General George Meade to employ land and naval forces to prevent the expedition. Proclamation of June 6, 1866, reprinted in 6 Compilation of the Messages and Papers of the Presidents 433 (J. Richardson ed. 1897).

${ }^{78}$ W. D'ARcy, supra note 72, at 163; L. O'Broln, supra note 72, at 67. President Johnson defended his intercession against the Fenians in his Second Annual Message to Congress in December 1866. "So long as those [neutrality] laws remain upon our statute books they should be faithfully executed, and if they operate harshly, unjustly, or oppressively Congress alone can apply the remedy by their modification or repeal." 6 COMPILATION OF THE Messages and Papers of the Presidents, supra note 77, at 445, 458.

70 Cong. Globe, 39th Cong., 1st Sess. 4048 (1866).

Bo H.R. 806, Cong. GLobe, 39th Cong., 1st Sess. 4197 (1866); see B. Jenkins, supra note 70 , at $181-83$.

81 W. D'Arcy, supra note 72, at 207; L. O'Broin, supra note 72, at 83. Father McMahon's sentence was commuted to 20 years' imprisonment in March 1867. See W. D'ARcy, supra note 72 , at 209 . His captivity received considerable attention in Congress until his release in August 1869. See id. at 311; H.R. REP. No. 7, 40th Cong., 2d Sess. (1868). Having been born in Ireland, Father McMahon was regarded as a British subject by the Canadian court and was convicted of treason. Cf. infra note 94 and accompanying text. Because treason is by definition a crime that can be committed only by one owing allegiance, see Kawakita v. United States, 343 U.S. 717, 722 (1952); Joyce v. Director of Public Prosecutions, 1946 A.C. 347,$365 ; 4$ W. Blackstone, Commentaries *74-75, his conviction was based on a denial of the efficacy of his American naturalization. Father McMahon was also denied the privilege of a mixed jury. $C$ f. infra notes 91,94 , and accompanying text. These defects did not escape the attention of Congress. See Cong. Globe, 40th Cong., 2d Sess. 419-20 (1868) (remarks of Rep. Shanks). But Father McMahon was not as gifted a publicist as Colonel Warren, who gave these issues their fullest notoriety. 
occurred in March 1867. The Irish Fenians coordinated a series of armed uprisings throughout their territory, though these were soon suppressed..$^{82}$ Nonetheless, the Fenian leadership called on their American brethren to send ships of armed men to join the remnants still fighting. ${ }^{83}$ A force of thirty-eight soldiers, including Civil War veterans Colonel William J. Nagle and Colonel John Warren, ${ }^{84}$ sailed from New York with a large cargo of arms on the Jacmel Packet, newly christened Erin's Hope. ${ }^{85}$ British authorities rounded them up a few hours after they landed and held them without charges; $;^{86}$ the writ of habeas corpus had been suspended in Ireland since February $1866,{ }^{87}$ largely due to the influx of Americans whose presence the British considered suspicious. ${ }^{88}$ The American minister in London, Charles Francis Adams, protested the detention of Nagle and Warren, ${ }^{89}$ and the United States government supplied their counsel when they were finally brought to trial in October $1867 .^{\circ 0}$

Nagle demanded trial by jury de mediatate linguae, a mixed jury of six British citizens and six aliens. The mixed jury was a privilege English law had long offered in suits between an alien and an English citizen, and it was still available in criminal cases. ${ }^{91}$ Nagle's trial was postponed while the authorities decided whether

s2 See L. O'BroIN, supra note 72, at 143-65.

ss See W. D'ARcy, supra note 72, at 243.

- Their honorable military records increased the popular pressure on behalf of Colonels Warren and Nagle. See W. D'ARcY, supra note 72, at 266; B. JENkINS, supra note 70, at 237.

ss See W. D'ARcY, supra note 72 , at 245.

so Id. at 247 ; B. JENKINS, supra note 70 , at 237.

${ }^{87}$ Habeas Corpus Suspension Act (Ireland), 1866, 29 \& 30 Vict., ch. 1.

s8 C. TANSILL, supra note 72, at 34. This belief was current at the time. See Cong. Globe, 40th Cong. 2d Sess. 946 (1868) (remarks of Rep. Robinson); C. TANSIII, supra note 72, at 34 (quoting letter of William West, American consul in Dublin, to Secretary of State William Seward (Feb. 17, 1866)); Morrow, The Negotiation of the Anglo-American Treaty of 1870, 39 AM. Hist. REv. 663, 663 \& n.1 (1934).

so W. D'ARcy, supra note 72, at 268. Adams, the son of John Quincy Adams and the father of Henry Adams, was unsympathetic to American Fenians and intervened on their behalf with reluctance. See, e.g., id. at 270; B. JENKINs, supra note 70, at 238-39. Adams's stiff correspondence with imprisoned Fenians made this attitude public knowledge, and proFenian elements in the House of Representatives sought to impeach him. See Cong. Grobe, 40th Cong., 1st Sess. 786-88 (1867); infra note 137 and accompanying text. Adams expressed his own desire to resign on more than one occasion and finally departed voluntarily in May 1868. See B. Jenkins, supra note 70, at 253, 268.

- W. D'ARcy, supra note 72, at 272.

21 See 3 W. Blackstone, Commentaries *360-61; Juries Act, 1825, 6 Geo. 4, ch. 50, § 47. The jury de mediatate linguae was abolished as part of the settlement of the naturalization question. See Naturalization Act, 1870, 33 \& 34 Vict., ch. 14, § 5. 
it was practicable to convene a mixed jury, and he was finally released in May 1868, after signing a confession and apology.92

Warren, unlike Nagle, had been born in Ireland and was an American citizen by naturalization. ${ }^{93}$ As expected, the court ruled that Warren was a British subject, not an alien, and rejected his demand for a mixed jury, citing the common law rule that a subject could not renounce his allegiance without the consent of the sovereign. ${ }^{94}$ Warren dismissed the counsel the American government had provided and announced that he was placing his case "in the hands of the United States which has now become the principal." ${ }^{95} \mathrm{He}$ thus succeeded in converting his case into a cause célèbre embodying a major recurring problem in United States diplomacy-the refusal of European states to recognize American naturalization as dissolving the subject's obligations to his former sovereign. Warren charged that his rights as an alien were doubly violated by his conviction-not only had he lost the mixed jury, but he was being punished solely for words spoken at Fenian meetings in the United States, an extraterritorial application of British penal law that would be legitimate only if he were a British subject. ${ }^{96}$ The claim that Great Britain was punishing Americans for

${ }^{22}$ W. D'ARCY, supra note 72, at 272; B. JENKINS, supra note 70, at 268.

${ }^{03}$ W. D'ARCY, supra note 72 , at 273.

9 See id. at 273. The common law rule of indefeasible allegiance is stated, e.g., in $1 \mathrm{~W}$. Blackstone, Commentakies *369-70. The federal judiciary had generally viewed the common law rule as still binding in the United States because no statute had superseded it, see, e.g., Shanks v. Dupont, 28 U.S. (3 Pet.) 242, 246 (1830) (Story, J.); 2 J. Kent, Commentaries * 49, while state courts had often agreed with the executive branch's view of free expatriation, see, e.g., Alsberry v. Hawkins, $39 \mathrm{Ky}$. (9 Dana) 177, 178 (1839) (citizens may repudiate their allegiance; the government may, however, limit this right by statute for the purpose of "preventing abuse and securing the public welfare").

9s B. Jenkins, supra note 70, at 250 (quoting from The Trmes (London) (Nov. 5, 1869)). D'Arcy gives the same quotation with a slight variation in the wording, taken from another contemporary source. W. D'ARCY, supra note 72, at 274.

${ }^{96}$ Cong. Globe, 40th Cong., 1st Sess. 787 (1867) (remarks of Rep. Robinson) (quoting letter from Warren (Aug. 2, 1869)). See also W. D'ARcy, supra note 72, at 275. D'Arcy points out that, as Senator Fessenden suggested at the time, Warren's words were in fact used as evidence of intent, not as the acts constituting the charge of treason. Id. at 275; see also Cong. Globe, 40th Cong., 2d Sess. 271 (1867) (remarks of Sen. Fessenden); B. JEnkins, supra note 70 , at $238,262$.

Under international law, the objection to Warren's prosecution was that British jurisdiction was not justified on the basis of territoriality (the power of a state to punish wrongful conduct occurring within its borders, no matter who the actor) or nationality (the power of a state to punish wrongful conduct by its citizens, no matter where it takes place). See generally George, Extraterritorial Application of Penal Legislation, 64 MicH. L. Rev. 609 (1966). In modern international law, other bases are available. The "objective principle" permits punishment of attempts, conspiracies, or other actions if they relate to a crime to be 
words spoken or acts performed in the United States evoked a strong determination in this country to vindicate America's sovereignty. ${ }^{97}$ Warren became the beneficiary of numerous resolutions passed by the House of Representatives, including one calling upon the President to take such "measures as will secure [his] return to our flag with such ceremonies as are appropriate to the occasion.","s

As Adams pointed out to Secretary of State William Seward, Adams's position as an American diplomat demanding recognition for Warren's status as an alien was compromised by American judicial acceptance of the common law doctrine of perpetual allegiance and Congress's failure to abrogate the rule by legislation.99 President Johnson called attention to this "singular and embarrassing conflict of laws" in his Third Annual Message to Congress:

British judges cite courts and law authorities of the United States in support of that theory against the position held by the executive authority of the United States. This conflict perplexes the public mind concerning the rights of naturalized citizens and impairs the national authority abroad. I called attention to this subject in my last annual message, and now again respectfully appeal to Congress to declare the national

committed within the state's jurisdiction. See Jurisdiction with Respect to Crime, 29 Aм. J. INT'L L. 437, 487-94 (Supp. 1935). There is also a possibility of jurisdiction under the "protective principle": certain crimes against the security of a state may be punished regardless of the nationality of the actor or the location of the act. See id. at 543-61. Although use of the protective principle is largely a recent innovation in Anglo-American criminal jurisdiction, the objective principle has a respectable common law ancestry in manipulative definitions of the locus delicti, and Congress was probably wrong in thinking that Warren could not be punished as an American coconspirator of the Irish Fenians. See, e.g., 1 J. BisHop, Commentaries on the Criminal Law 592 (2d ed. Boston 1858) (1st ed. Boston 1856) (footnotes omitted):

[T] hough the gist of conspiracy is the unlawful combination, so that the offense is cognizable only in some county where such mental concord took place; yet, as in point of law the conspirators renew the conspiracy with every act done by any one of them in carrying out the plan, they may be indicted either in the county in which they first entered into the unlawful combination, or in any other county in which, in pursuance of it, any overt act is performed.

For the purpose of understanding the legislative history of the Citizens in Foreign States Act, however, the important point is that many members of Congress believed that political speech by naturalized citizens in America was being punished because the British viewed the speakers as subjects of the Crown, and that these members considered it self-evident that a similar prosecution of native Americans was impermissible under international law.

${ }^{07}$ See, e.g., H.R. REp. No. 13, 40th Cong., 2d Sess. 2 (1868); Cong. Globe, 40th Cong., 2d Sess. 269 (1867) (remarks of Sen. Conkling).

${ }^{98}$ Cong. Globe, 40th Cong., 2d Sess. 3175 (1868).

22 B. Jenkins, supra note 70, at 250-51 (quoting letter from Adams to Seward (Nov. 5, 1867)); see supra note 94 . 
will unmistakably upon this important question. ${ }^{100}$

The requisite declaration was supplied in the Citizens in Foreign States Act, whose first section provides "[t]hat any declaration, opinion, order, or decision of any officers of this government which denies, restricts, impairs, or questions the right of expatriation, is hereby declared inconsistent with the fundamental principles of this government." 101

While Warren was awaiting trial, the prospects for a conciliatory release were greatly diminished by a Fenian adventure within England and the public outcry it produced. In September 1867, the British captured Colonel Thomas Kelly, a Civil War veteran who had succeeded James Stephens as the leader of the Fenians in Ireland. ${ }^{102}$ A rescue party liberated Kelly from a police van in Manchester; while attempting to shoot open the lock, they killed one Sergeant Brett, who was peering through the keyhole. ${ }^{103}$ Kelly and his fellow prisoner Deasy escaped, but more than twenty others were arrested. Three were hanged on November 23, 1867. ${ }^{104}$

The murder of the Manchester policeman created anti-Fenian hysteria in England, but the hanging of the "Manchester Martyrs" gave new life to the Fenian movement in Ireland and America. ${ }^{105}$ Furthermore, one of the martyrs was a United States citizen named Michael O'Brien, and it became public knowledge that Adams had refused to intercede on his behalf. ${ }^{108}$ The Manchester tragedy thus increased the self-righteousness of both sides and reinforced the impression among the Fenians and their sympathizers

1006 Compilation of the Messages and Papers of the Presidents, supra note 77, at 558, 580-81 (Dec. 3, 1867); see also id. at 445, 458-59 (Second Annual Message) (Dec. 3, 1866).

${ }^{10 x}$ See supra note 44 . This section is one of many examples illustrating that Congress often dislikes the tenor of judicial opinions as to fundamental law and is not inhibited from invoking its legislative power to correct "heresies" of the Third Branch. The phenomenon is not so novel as some have thought.

${ }^{102}$ See L. O'Broln, supra note 72, at 119-24, 192-94.

${ }^{103}$ B. Jenkins, supra note 70, at 241; L. O'Broin, supra note 72, at 194.

104 B. Jenkins, supra note 70, at 244-46; L. O'BroIN, supra note 72, at 202.

108 B. Jenkins, supra note 70, at 246-47; see also L. O'Brols, supra note 72, at 202-09.

${ }^{108}$ W. D'ARcy, supra note 72, at 269-72; B. JENkiNs, supra note 70, at 244-46. O'Brien had denounced Adams at his trial, id. at 245; CoNG. GLoBE, 40th Cong., 1st Sess. 788 (1867) (remarks of Rep. Robinson, including O'Brien's reported speech and Adams's extraordinary reply to O'Brien's request for help), but he appears not to have made his citizenship an issue in any other way. On the other hand, Adams had secured a reprieve for Condon, the other American among the five condemned rescuers, in the belief that he was less culpable than O'Brien, and Condon was ultimately pardoned. W. D'ARcy, supra note 72 , at 270-71 \& n.117; B. JENKINS, supra note 70 , at $245-46$. 
that the Johnson administration was not sufficiently committed to protecting its citizens from British tyranny.

The various issues raised by the arrests of O'Brien, Warren, Nagle, and Father McMahon reappeared in less prominent cases as well and were the subject of much comment on the floor of Congress. ${ }^{107}$ The numerous outrages attributed to the British, including suspension of habeas corpus to facilitate arrest of Irish-Americans on suspicion, indefinite postponement of trial, refusal of mixed juries, inquiry into words spoken and acts performed in the United States, conviction of naturalized Americans for treason against the Crown, and reliance on paid informers for evidence of guilt, all combined to fuel American indignation against the punishment of Fenians who fell into British hands. Fenian sympathizers urged the United States to follow the example of Great Britain itself, which had recently sent a military expedition against King Theodorus of Abyssinia after he had ordered wholesale arrests of British subjects in retaliation for a British conspiracy against him that he had detected. ${ }^{108}$

Throughout this period, American Fenians had been announcing the impendency of another invasion of Canada. ${ }^{109}$ Seward sought to exploit this threat in prodding the British for a speedy settlement of the naturalization question, but intelligence sources kept the British government informed of the administration's efforts to prevent a repetition of the 1866 border incident. ${ }^{110}$ The negotiations finally bore fruit with the signing of a protocol in October 1868, agreeing on the principle of free renunciation of allegiance. $^{111}$ The protocol contemplated further study by Parlia-

${ }^{107}$ See, e.g., Cong. GroBe, 40th Cong., 1st Sess. 561 (1867) (remarks of Rep. Robinson) (discussing Stephen Meany, allegedly tried for acts performed in America); id. at 756 (remarks of Rep. Robinson) (discussing the similar plight of Captain McCafferty); id. at 788-89 (remarks of Rep. Robinson) (five Americans allegedly imprisoned for 20 months without charges being brought); Cong. GLOBE, 40th Cong., 2d Sess. 420 (1868) (remarks of Rep. Paine) (discussing Father McMahon's fellow prisoner Lynch); id. at 969 (remarks of Rep. Judd) (summarizing wrongs: Americans were "treated with contumely and contempt, impressed into military service, imprisoned for no offense, punished without crime, and when charged with crime denied in the administration of laws the privileges accorded to every other nationality").

108 See Cong. Globe, 40th Cong., 1st Sess. 789 (1867) (remarks of Rep. Robinson); Cong. Globe, 40th Cong., 2d Sess. 4207 (1868) (remarks of Sen. Conness); id. at 4237 (remarks of Sen. Stewart).

${ }^{108}$ See B. JENkINS, supra note 70, at 269-73.

110 See id.

111 See Protocol Showing United States and British Governments' Agreement on Naturalization, reprinted in Papers Relating to Foreign Afrairs (1868 pt. 1) 359-60 (1869). 
ment, ${ }^{112}$ which resulted in the Naturalization Act of $1870^{113}$ and a Naturalization Treaty signed in May $1870 .{ }^{114}$ One casualty of the settlement process was that troublesome institution, the jury de mediatate linguae; it had, of course, never been a requirement of international law, and was abolished by Parliament in the Naturalization Act. ${ }^{115}$

With the defusion of the naturalization controversy and the return of most American prisoners, the tension in this country abated and the prospect of war with Great Britain receded. ${ }^{118}$ After the long-promised raid on Canada was foiled by Canadian and American troops in May $1870,{ }^{117}$ the public largely lost interest in the American Fenian leadership. ${ }^{118}$

Incidents involving the treatment of naturalized Americans in continental Europe also received a significant amount of congressional attention. ${ }^{118}$ Many European governments imposed a term of compulsory military service on all male subjects, and emigrants who left before meeting this obligation were punished if they ever returned as visitors to their homelands. ${ }^{120}$ In 1868, the United States signed a series of treaties with various German states, guaranteeing respect for naturalization after five years' continuous residence in the United States, and abandoning the claim for military service unless the individual had fled while actually serving in the army. ${ }^{121}$ Although these issues did not inspire the degree of emo-

112 See B. Jenkins, supra note 70, at 278-79.

11333 \& 34 Vict., ch. 14.

11 Naturalization Treaty, May 13, 1870, United States-United Kingdom, 16 Stat. 775, T.S. No. 130.

115 See supra note 91. Senator Reverdy Johnson, who later would negotiate the 1868 naturalization protocol, pointed out in one of the early Senate debates on protection of citizens that Great Britain was free to eliminate the mixed jury. Cong. Grobe, 40th Cong., 2d Sess. 269 (1867).

118 See B. JENkins, supra note 70 , at $280-81$.

11 W. D'ARCY, supra note 72, at 350-56; B. JENKINs, supra note 70, at 306. There was one last raid in October 1871, but only 40 men were involved. W. D'ARCY, supra, at 381-82.

118 B. JENKINS, supra note 70, at 320.

11 See, e.g., Cong. Globe, 40th Cong., 2d Sess. 1099 (1868) (remarks of Rep. Hunter) (regarding individuals of Prussian and of French origin). The descriptions of these incidents on the floor of Congress are straightforward and self-contained, and do not require the background explanations needed to illuminate the continual references to prominent Fenians.

120 See, e.g., H.R. REP. No. 13, 40th Cong., 2d Sess. 8-10, 20-22 (1868); O. zu StolbergWernigerode, Germany and the United States of America During the Era of Bismarck 100-01 (Lessing trans. 1937).

${ }^{121}$ See Naturalization Treaty, Feb. 22, 1868, United States-North German Confederation, 15 Stat. 615, T.S. No. 261; Naturalization Treaty, May 26, 1868, United States-Bavaria, 15 Stat. 661, T.S. No. 18; Naturalization Treaty, July 19, 1868, United States-Baden, 16 
tional fervor in the congressional debates that the Fenian crisis did, they contributed to the drive behind the Citizens in Foreign States Act; like the Irish-Americans, German-Americans were a considerable political force. ${ }^{122}$

\section{B. The Legislative History}

The Citizens in Foreign States Act was a product of the Fortieth Congress, the body that also conducted the impeachment trial of Andrew Johnson, ${ }^{123}$ but the legislative context of the Act began with a series of measures introduced in the Thirty-ninth Congress. The immediate stimulus for action was President Johnson's interference with Fenian assaults on Canada, especially the proclamation and arrests that followed the attempted invasion of Ontario in June 1866. ${ }^{124}$ Some representatives saw no need for greater solicitude toward Great Britain than that country had displayed toward our government in the Civil War, and they proposed resolutions calling for repeal of the strict American neutrality laws, recognition of the Fenians as lawful belligerents, and expression of official sympathy with the Irish cause. ${ }^{125}$ In July, the House actually

Stat. 731 , T.S. No. 15; Naturalization and Extradition Treaty, July 27, 1868, United StatesWurttemberg, 18 Stat. 811, T.S. No. 375; Naturalization Treaty, Aug. 1, 1868, United States-Hesse, 16 Stat. 743, T.S. No. 171. Similar treaties were also signed with Belgium and Mexico that year, and with the Kingdom of Sweden and Norway in 1869. See Naturalization Treaty, July 10, 1868, United States-Mexico, 15 Stat. 687, T.S. No. 213, Naturalization Treaty, Nov. 16, 1868, United States-Belgium, 16 Stat. 747, T.S. No. 24; Naturalization Treaty, May 26, 1869, United States-Sweden \& Norway, 17 Stat. 809, T.S. No. 350. The precise wording of the treaties differed, and the treaty with the North German Confederation (which included Prussia) was criticized in the debates on the Citizens in Foreign States Act as not going far enough. See Cong. Globe, 40th Cong., 2d Sess. 4211 (1868) (remarks of Sen. Howard); id. at 2316 (remarks of Rep. Banks).

122 See the cynical analysis by Senator William Fessenden of the relative stakes of the Democratic and Republican parties in the issue, $i d$. at 4331; see also id. at 986 (Rep. Judd reports " $[t]$ he whole German press is in a rage" over the House committee's first version of the bill.).

${ }^{123}$ The House adopted articles of impeachment in early March 1868, but President Johnson was acquitted by the Senate on May 26. The original House bill, H.R. 584, CoNG. GloBe, 40th Cong., 2d Sess. 738 (1868), was reported in late January 1868 and recommitted in February; the House passed the second version, H.R. 768, Cong. GLoBE, 40th Cong., 2d Sess. 1797 (1868), on April 20, Cong. Grobe, 40th Cong., 2d Sess. 2317-18 (1868), and the Senate passed it with amendments on July 25, after a week of debate. See Cong. Globe, 40th Cong., 2d Sess. 4446 (1868).

${ }^{124}$ See supra notes 76-78 and accompanying text.

${ }_{128}$ See Cong. Globe, 39th Cong., 1st Sess. 3085-86 (1866). The resolutions were referred to the Committee on Foreign Affairs. Representative Abner Harding's resolution condemned President Johnson's "zeal and alacrity to aid an oppressor to an extent not imperatively required by the observed law of nations" as "ignominious and disgraceful." Id. 
passed a bill intended "to modify our [neutrality] statutes to correspond with the statutes of Great Britain,"126 but it suffered a slow death in the Senate Foreign Relations Committee. ${ }^{127}$ The House also adopted resolutions urging the release of Fenians captured in $\mathrm{Canada}^{128}$ and requesting the President to drop the prosecutions of those arrested here. ${ }^{129}$

In the spring of 1867, the Fortieth Congress continued this interest in the Fenian struggle. The House Committee on Foreign Affairs reported a resolution extending the sympathy of the House to the Irish people in their "efforts to maintain the independence of States ... and to extend and perpetuate the principles of liberty"; it received overwhelming support. ${ }^{130}$ The House passed further resolutions requesting information from the President regarding arrests of Americans by Great Britain ${ }^{131}$ and the trials of the Fenians in Canada. ${ }^{132}$ But indignation began to replace concern in the summer of 1867, after the arrests of Colonels Warren and Nagle and their comrades of the Erin's Hope expedition. The House called on its Foreign Affairs Committee and the President to detail British arrests and convictions of American citizens for words spoken or acts done in the United States, ${ }^{133}$ and it urged the President to "take proper measures."134

Dissatisfaction with the Johnson administration's performance had already surfaced in the debates, ${ }^{135}$ but it took a particularly

${ }^{126}$ H.R. 806, Cong. Globe, 39th Cong., 1st Sess. 4195 (1866) (remarks of Rep. Banks, Chairman of the Committee on Foreign Affairs). See id. at 4193-97 (debate and passage of H.R. 806). The bill would have, among other things, lowered the penalties from fine and imprisonment to fine or imprisonment, eliminated the bounties paid to informers, and repealed the section forbidding persons to set on foot a military expedition against a state with whom the United States was at peace. See Act of April 20,1818, ch. 88, §§ 1, 3, 5, 6, 3 Stat. 447, 447 (current version at 18 U.S.C. $\$ \S 958-960$ (1976)).

${ }_{127}$ See Cong. GLOBE, 39th Cong., 2d Sess. 1893 (1867) (committee discharged from further consideration of bill for that session); B. JENkiNs, supra note 70, at 183-84.

${ }_{128}$ Cong. Grobe, 39th Cong., 1st Sess. 4047 (1866).

128 Id. at 4048.

130 See Cong. GLoBe, 40th Cong., 1st Sess. $392-94$ (1867). The resolution also extended sympathy to the inhabitants of Candia (Crete), who were then attempting to overthrow their Ottoman rulers.

131 Id. at 18.

132 Id. at 188.

133 Id. at 561.

134 Id. at 756.

${ }^{135}$ See id. (remarks of Rep. Robinson); Cong. Globe, 39th Cong., 1st Sess. 4196 (1866) (remarks of Rep. Conkling). The debates on the Citizens in Foreign States Act itself are replete with sarcastic observations on the capacities of "the present Executive." See, e.g., ConG. GLOBE, 40th Cong., 2d Sess. 4355 (1868) (remarks of Sen. Conkling); id. at 1102 (re- 
vivid form in the fall of 1867, when Representative William Robinson, a member of the Committee on Foreign Affairs and a prominent Fenian supporter, ${ }^{136}$ sought to impeach Charles Francis Adams, the American minister in London. ${ }^{137}$ Robinson's speech came two days after the hanging of the "Manchester Martyrs" and alleged a policy of neglect toward the rights of Irish-Americans. ${ }^{138} \mathrm{In}$ closing, he introduced yet another resolution, requesting the Foreign Affairs Committee to report a bill specifying "how far we shall protect the rights of natives of other countries naturalized in the United States."139 With this resolution the controversy broadened to embrace the entire naturalization question, and the defenders of the Fenians were able to enlist the support of German-Americans whose freedom to travel in Europe was clouded by claims for military service by their native lands. ${ }^{140}$ Two months later, the Committee reported "A bill concerning the rights of American citizens in foreign States," the first version of the Act. ${ }^{141}$

Although much of the debate shifted to a more abstract plane, with learned disquisitions on the law of nationality, ${ }^{142}$ the legislators never ceased to be conscious that notorious individual cases had focused public attention on the issue. Representatives continued to introduce resolutions for the benefit of McMahon, Nagle, and Warren, ${ }^{143}$ and the House passed a bill appropriating $\$ 50,000$ for the relief and return fares of citizens wrongfully imprisoned abroad. ${ }^{144}$ On one occasion, a unanimous consent request for a res-

marks of Rep. Ashley).

136 See, e.g., CoNG. Globe, 40th Cong., 1st Sess. 392-93 (1867) (remarks of Rep. Robinson on sympathy resolution). For other resolutions introduced by Robinson, see id. at 18, 561, 786 (1867); Cong. Globe, 40th Cong., 2d Sess. 945, 3175 (1868).

137 See supra note 89. Adams's recall was also the subject of a joint resolution introduced by Representative Robert Van Horn in 1868. H.R.J. Res. 159, CoNG. GLOBE, 40th Cong., 2d Sess. 636 (1868).

138 Cong. Globe, 40th Cong., 1st Sess. 786-89 (1867).

139 Id. at 791.

${ }^{140}$ See Cong. Globe, 40th Cong., 2d Sess. 268-69 (1867) (remarks of Sen. Sherman); id. at 1156-57 (remarks of Rep. Jenckes).

141 Id. at 783.

${ }^{142}$ See, e.g., H.R. REp. No. 13, 40th Cong., 2d Sess. (1868); Cong. Globe, 40th Cong., 2d Sess. 1013-14 (1868) (remarks of Rep. Chanler); id. at 1100-01 (remarks of Rep. Baker), id. at 1802-03 (remarks of Rep. Van Trump).

${ }^{343}$ See Cong. Globe, 40th Cong., 2d Sess. 309-10 (1868) (introduced by Rep. Price); id. at 945 (introduced by Rep. Robinson); H.R.J. Res. 139, Cong. Globe, 40th Cong., 2d Sess. 420 (1868) (re Warren and Nagle; introduced by Rep. Wood; passed by House but died in Senate); H.R.J. Res. 137, Cong. Grobe, 40th Cong., 2d Sess. 385 (1868).

${ }_{144}$ H.R. 763, Cong. Globe, 40th Cong., 2d Sess. 1243-44 (1868). Nagle and some of his comrades applied for the money, thinking that the bill had become law. W. D'ARcY, supra 
olution addressed generally to the rights of "native and adopted citizens" was denied by an objector who commented, "We have had enough of the Fenians."145

Language in Congress grew more impassioned and belligerent as letters arrived from Warren and Nagle, exaggerating the misconduct of the British. ${ }^{146}$ Though much of the militarism was probably rhetorical, the Fenians stood to benefit greatly if Congress heeded Warren's plea “to compel England to expunge from her law-books every presumption bearing on the rights of the American citizen [or to] wipe her from the face of the earth."147 Some members of Congress did not conceal their eagerness for war with Great Britain, welcoming the opportunity to further the Fenians' national goals in Ireland and Americans' territorial ambitions in Canada. ${ }^{148}$

Foreign Affairs Committee Chairman Nathaniel Banks used more pacific rhetoric when he finally reported the bill for the protection of naturalized American citizens to the House, ${ }^{148}$ but the aggressive potential of the bill was obvious from its remedial section:

[W] henever it shall be duly made known to the President that any naturalized citizen of the United States has been arrested or detained by any foreign Government, in contravention of the intent and purpose of this Act, upon the allegation that naturalization in the United States does not operate to dissolve his allegiance to his native sovereign, or if any citizen shall have been so arrested and detained whose release upon demand shall have been unreasonably delayed or refused, the

note 72 , at 289 .

14 Cong. Globe, 40th Cong., 2d Sess. 505 (1868) (remarks of Rep. Dawes).

${ }^{148}$ See id. at 270 (Warren); id. at 309-10 (Nagle); id. at 418 (Warren); Cong. GLobe, 40th Cong., 1st Sess. 561 (1867) (Nagle); id. at 787 (Warren). Not everyone in Congress, of course, believed the Fenians' accounts of their ordeals. See, e.g., Cong. GLOBE, 40th Cong., 2d Sess. 271 (1867) (remarks of Sen. Fessenden); id. at 4212 (remarks of Sen. Drake).

147 Cong. Globe, 40th Cong., 2d Sess. 270 (1867).

148 See id. at 418-19 (remarks of Rep. Wood) ("If this course shall cause hostilities let them come. If they do come the great problem of self-government will be worked out in the Emerald Isle . . . ."); id. at 4238 (remarks of Sen. Stewart):

I think the least calamity that could happen to America would be a war with Great Britain. . . . I think we shall pay off some old scores. She has large possessions at the North, and I do not think that the boundaries of our country will be contracted or the area of the United States become less by reason of the conflict.

149 See, e.g., CoNG. GLoBe, 40th Cong., 2d Sess. 1799-1800 (1868) (reprisal bill is "a wise and Christianlike proceeding . . . ; it will prevent war."). 
President shall be, and hereby is, empowered to order the arrest and to detain in custody any subject or citizen of such foreign Government who may be found within the jurisdiction of the United States; and the President shall, without unreasonable delay, give information to Congress of any such proceedings under this act. ${ }^{150}$

The propriety, efficacy, and decency of this reprisal provision were major subjects of debate, and the Senate ultimately excised it. But the House Committee's first version of the bill had other faults as well. Several representatives objected to the bill's failure to declare euphoniously the inalienable right of expatriation and to its indirect approach to overturning the contrary common law doctrine. ${ }^{151}$ The bill also included a list of exceptional situations in which the government would not intercede; these were thought to discriminate against naturalized citizens and might have left most German-Americans unprotected against claims for military service. ${ }^{152}$ Finally, a thoroughly vague portion of the bill empowered the President "to employ all the resources of the Government in just efforts to secure the recognition by other Governments" of the principles it enunciated. ${ }^{16 s}$ After Representative Banks declined to explain the scope of this provision, many members of the House condemned it as granting too much discretion, and as possibly conferring the war power on the executive. ${ }^{154}$ The Committee withdrew the bill and only reported it back after major changes. ${ }^{155}$

${ }^{130}$ H.R. 584, § 2, Cong. GloBe, 40th Cong., 2d Sess. 783 (1868) (emphasis added).

151 Banks had sought to avoid any implication that governments have the power to modify by positive law an individual's right to free expatriation, see CoNG. GLOBE, 40th Cong., $2 d$ Sess. 832-33, 1128 (1868), and had framed the bill as if the United States government had always "insisted upon and maintained" this principle, see H.R. 584, § 1, ConG. GLOBE, 40th Cong., 2d Sess. 783 (1868). Congressmen who wanted a ringing declaration of rights were willing to risk the former implication and feared that the latter tactic would undermine the intelligibility of the bill. See, e.g., Cong. Grobe, 40th Cong., 2d Sess. 868 (1868) (remarks of Rep. Wilson); id. at 1128 (remarks of Rep. Jenckes).

${ }^{152}$ See, e.g., Cong. Globe, 40th Cong., 2d Sess. 986 (1868) (remarks of Rep. Judd); id. at 1099 (exchange between Rep. Cook and Rep. Banks).

${ }^{163}$ H.R. 584, \& 1, CoNG. GloBe, 40th Cong., 2d Sess. 783 (1868).

254 See Cong. Globe, 40th Cong., 2d Sess. 865 (1868) (exchange between Rep. Ward and Rep. Banks); id. at 866 (remarks of Rep. Ward); id. at 967 (remarks of Rep. Bailey); id. at 969 (remarks of Rep. Judd).

${ }^{185}$ Id. at 1160. Compare H.R. 584, Cong. Globe, 40th Cong., 2d Sess. 783 (1868) with H.R. 768, Cong. Globe. 40th Cong., 2d Sess. 1797 (1868). The substantive sections of the bill were now preceded by a long preamble, recognizing expatriation as a "natural and inherent right"; in section 1, decisions or orders of the government inconsistent with that right were declared void; in section 2 , the first sentence of the original first section, promising the same protection to naturalized citizens that the native-born received, was retained, but the 
The reprisal clause, however, was virtually untouched, ${ }^{158}$ and the arguments directed to that provision were the same before and after recommittal. Representative Banks and other members of the Committee spoke in favor of reprisals and the threat of reprisals as effective means of forcing foreign governments to respect the United States' position on nationality. ${ }^{167}$ But other congressmen viewed deliberate reprisal arrests of innocent foreign travelers as certain to provoke war and opposed "delegat[ing] to the President the power vested in Congress alone by the Constitution"158 - the power to declare war. ${ }^{169}$ They also denounced the reprisal method as barbarous ${ }^{160}$ and unlikely to achieve any advantage for imprisoned Americans. ${ }^{161}$

These critics proposed a variety of alternative remedial provisions for the bill, empowering the President to suspend commercial relations with the offending state wholly or in part, or to blockade its ports; ${ }^{162}$ requiring him to cease all diplomatic and commercial

remainder of that section, containing the vague "empowering" provision and the unpopular exceptions, was dropped; sections 3 and 4 of the original bill, constituting another exception, were also eliminated. The preamble and the first two sections of this second version were enacted without major changes, unlike section 3 .

${ }^{168}$ If anything, its scope was broadened. The committee had merely dropped two words from section 2 of the bill originally reported: "naturalized" and "so." The intended effect of the latter change is unclear; taken literally, it might have extended the applicability of the bill beyond the issue of citizenship. Compare Cong. GLoBE, 40th Cong., 2d Sess. 4234 (1868) (remarks of Sens. Morton and Conness) with id. at 4237 (remarks of Sens. Williams and Stewart). The language ultimately enacted does not possess this ambiguity.

${ }^{167}$ See, e.g., id. at 1798 (remarks of Rep. Banks); id. at 1108 (remarks of Rep. Orth); id. at 1805 (remarks of Rep. Morgan); id. at 945 (remarks of Rep. Robinson, offering resolution for immediate passage that would have "requested" the President to order reprisal arrests). Representative Fernando Wood, one of the pro-Fenians openly approving of war with Great Britain, see supra note 148, suggested extending reprisals onto the high seas. See Cong. GLose, 40th Cong., 2d Sess. 2030 (1868).

${ }^{168}$ Cong. Globe, 40th Cong., 2d Sess. 1131 (1868) (remarks of Rep. Woodbridge).

${ }^{159}$ Id.; see id. at 986 (remarks of Rep. Judd); id. at 1099-1100 (remarks of Rep. Baker); id. at 1106 (remarks of Rep. Clarke); id. at 2313 (remarks of Rep. Eliot).

${ }^{160}$ See, e.g., id. at 866 (remarks of Rep. Donnelly); id. at 869 (remarks of Rep. Pile). Representative Burton Cook sought to demonstrate the injustice and futility of the measure by hypothesizing that the President might seize as a hostage Charles Dickens, who was then on his second American tour. See id. at 1099. The same point was made in the Senate, see, e.g., id. at 4206 (remarks of Sen. Sumner). Just before the passage of the bill, Representatives Henry Dawes and Norman Judd also questioned the constitutionality of the bill from the point of view of the arrested alien. Representative Banks, however, dismissed the notion that habeas corpus or the Bill of Rights had any relevance to reprisal arrests, which did not "come within the pale of the criminal law in any way whatever." Id. at 2314, 2315.

161 See, e.g., id. at 1016 (remarks of Rep. Chanler); id. at 1100 (remarks of Rep. Baker); id. at 986 (remarks of Rep. Judd) ("As a means of redressing a wrong the proposition is a farce, and as a mode of punishment it is a barbarism.").

${ }^{162}$ Id. at 869 (remarks of Rep. Pile). This proposal would still have permitted reprisals 
intercourse with that state; ${ }^{168}$ and requiring him to interpose with "promptitude and energy" on behalf of the victims. ${ }^{164}$ Other proposals included vague statements of a duty to protect ${ }^{165}$ and declarations that the foreign state's action would be "considered just cause of war"168 or "regarded as an offense to the nation, incompatible with the continuance of friendly relations."167 One congressman, agreeing with all the objections raised against the bill, announced that he would vote for it anyway, "trusting that a fuller discussion in the Senate than has been allowed us here will secure the adoption of amendments which will make it more acceptable than it is now."188

The House made only minor changes in the reprisal section. Representative William Pile's amendment empowered the President to suspend commercial relations and authorized arrests "in case no other remedy is available." to the reprisal clause, exempting ambassadors and their households and aliens who had declared an intention to become American citizens. ${ }^{170}$ After the failure of a last attempt to substitute a declaration that the foreign state's action would be "incompatible with friendly relations," 171 the bill passed overwhelmingly. ${ }^{\mathbf{1 7 2}}$

as a last resort. After the blockading of ports had been dropped from its language, Representative Pile's amendment was adopted. See infra note 169 and accompanying text.

10s Cong. Globe, 40th Cong., 2d Sess. 968 (1868) (remarks of Rep. Butler).

164 Id. at 1101 (remarks of Rep. Baker).

${ }^{165}$ Id. at 968 (remarks of Rep. Jenckes); id. at 1129 (remarks of Rep. Judd). Representative Zachariah Chanler proposed eviscerating the remedial section and viewed an international congress on the nationality question as the true solution. See id. at 1012.

${ }^{160}$ Id. at 831 (remarks of Rep. Spalding).

167 Id. at 1799 (remarks of Rep. Eliot).

108 Id. at 1102 (remarks of Rep. Ashley).

160 Id. at 2311-12, 2317 (remarks of Rep. Pile).

170 Id. at 2311, 2317 (remarks of Reps. Paine and Coburn).

171 See id. at 2317 . The vote was 51 to 59 , with 79 not voting. Forty-five of the amendment's supporters then voted in favor of the bill. See id.

${ }^{172}$ See id. Only four representatives voted against the bill. As passed by the House, the third section read:

That whenever it shall be duly made known to the President that any citizen of the United States has been arrested and is detained by any foreign Government in contravention of the intent and purposes of this act, upon the allegation that naturalization in the United States does not operate to dissolve his allegiance to his native sovereign; or if any citizen shall have been arrested and detained whose release upon demand shall have been unreasonably delayed or refused, the President shall be, and hereby is, empowered to suspend in part, or wholly, commercial relations with the said Government, or in case no other remedy is available, to order the arrest and to detain in custody any subject or citizen of such foreign Government who may be found within the jurisdiction of the United States, and who has not declared his intention to become 
The bill was then sent to the Senate, which referred it to the Committee on Foreign Relations chaired by Senator Charles Sumner. ${ }^{173}$ Its fate was uncertain; Sumner had been able to kill Representative Banks's bill to revise the neutrality laws in the previous Congress. ${ }^{174}$ When the reprisal bill was still in embryonic form, Senator John Conness of California, who would provide the leading voice for the extreme Fenian supporters in the Senate debate, ${ }^{175}$ had openly "ask[ed] the honorable chairman of the Committee on Foreign Relations not to suppress this subject."176 The Committee held onto the bill for almost three months and only reported it after Senator Conness had begun an attempt to discharge the Committee of the bill. ${ }^{177}$

In the meantime, the international situation had improved slightly. Nagle was released in May, ${ }^{\mathbf{1 7 8}}$ and a naturalization treaty between the United States and Bavaria joined the Prussian treaty of the preceding February, with three more German treaties imminent that summer. ${ }^{179}$ Senator Reverdy Johnson replaced Adams as minister in London, ${ }^{180}$ and the appointment of a Royal Commission to study the naturalization question foreshadowed the protocol Johnson would sign in October. ${ }^{181}$ President Johnson had survived impeachment in May, but his term was ending, and senators looked forward to "an Executive in whom a majority of the mem-

a citizen of the United States, except embassadors and other public ministers and their domestic servants, and the President shall, without delay, give information to Congress of any proceedings under this act.

173 Id. at 2329.

174 See B. Jenkins, supra note 72, at 184, 274; supra note 127 and accompanying text.

175 Senator Conness, himself a naturalized citizen, see Cong. GLoBE, 40th Cong., 2d Sess. 268-69 (1867), led the supporters of the House reprisal bill, which he sought to toughen by deleting Representative Pile's language making reprisals a last resort. See id. at 4206-08. He characterized various weakening amendments introduced on the Senate floor as "effeminate" and "impotent," and as insults to naturalized citizens. Id. at 4331, 4349, 4353.

${ }^{176} I d$. at 268.

${ }^{177}$ See id. at 3347, 3389; B. JenkINs, supra note 70, at 274 (suggesting that Sumner's hand was forced by the need to pass some kind of bill on the subject before the 1868 elections).

${ }^{178}$ See supra note 92 and accompanying text.

179 See supra note 121 . The treaties were, however, not entirely satisfactory to some senators, because they required a naturalized American to accumulate five years' residence in this country if his, change of allegiance was to be recognized. See Cong. GLobe, 40th Cong., 2d Sess. 4211 (1868) (remarks of Sen. Howard).

${ }^{180}$ See Conc. GLOBE, 40th Cong., 2d Sess. 4329 (1868) (remarks of Sen. Vickers); Morrow, supra note 88 , at 675 .

${ }^{181}$ See B. Jenkins, supra note 70, at 268. 
bers of this body have confidence."182 Nonetheless, pressure for passage of a bill for the protection of American citizens remained high. Colonel Warren still lay "in a British bastile, clothed in a suit of convict gray,"183 and the newspapers had not forgotten him. ${ }^{184}$ Nor had the Republican and Democratic parties, both of whose 1868 platforms included planks calling for equal protection of native and naturalized citizens abroad. ${ }^{185}$ The bill retained its political importance, and senators made repeated reference to this fact in the debates. ${ }^{186}$

Once on the floor, the bill took several successive forms as shifting coalitions of senators adopted and repealed amendments. Sumner spoke passionately against reprisals, and the Senate accepted the Committee's recommendation to strike that section of the House bill and substitute a provision merely requiring the President to report incidents to Congress. ${ }^{187}$ Shortly thereafter, this was replaced by yet another substitute, proposed by Senator George Williams of Oregon, which consisted of the language of the third section as ultimately enacted. ${ }^{188}$ This version, however, was itself stricken and was followed by two further alternatives before the Senate returned to Senator Williams's amendment. ${ }^{189}$

${ }_{182}$ Cong. Globe, 40th Cong., 2d Sess. 4355 (1868) (remarks of Sen. Conkling).

183 The phrase is quoted from the petition Warren sent to Senator Henry Wilson, quoted in Cong. Globe, 40th Cong., 2d Sess. 270 (1867).

184 See Cong. Globe, 40th Cong., 2d Sess. 4354 (1868) (Sen. Conness, reading from the New York Sun). Nor had the House forgotten him, for it adopted yet another resolution on his behalf on June 15. See Cong. GlobE, 40th Cong., 1st Sess. 3175 (1868).

183 See 1 National Party Platrorms 37-40 (D. Johnson ed. 1978). The Democratic platform also demanded "the assertion of American nationality, which shall command the respect of foreign powers, and furnish an example and encouragement to people striving for national integrity, constitutional liberty, and individual rights" (emphasis added), while the Republican platform made explicit mention of "arrest and imprisonment by any foreign power, for acts done or words spoken in this country."

186 See, e.g., Cong. Globe, 40th Cong., 2d Sess. 4330 (1868) (remarks of Sen. Williams) ("Why is it, if everything has been so smooth and so placid upon this subject, that both of the political parties of this country have seen proper to put in their platforms resolutions in reference to the rights of American citizens abroad?"); id. at 4331 (Sen. Fessenden's sardonic reply). No doubt another indicator of the political significance of the bill may be seen in disclaimers like that of Senator Conness: "I do not speak, Mr. President, for votes; let no man say so." Id. at 4208.

${ }^{187}$ Id. at 4330 . Senator Conness's amendment to strike the words in the House bill empowering suspension of commercial relations and making reprisals only a last resort had already passed, but it was supported by opponents of reprisals as well as supporters, because striking part of the section was perfectly consistent with striking all of it later. See id. at 4329 (remarks of Sen. Sumner and Sen. Harlan).

188 Id. at 4330. This language is reprinted supra note 39.

180 See id. at 4349 (Buckalew amendment); id. at 4352-53 (Howard amendment); id. at 
Senators expressed the same objections to the reprisal provision as had been heard in the House: it was ineffective, ${ }^{190}$ barbarous, ${ }^{191}$ certain to lead to war, $^{192}$ and an unconstitutional delegation of the war power. ${ }^{193}$ One senator hinted that the reprisal remedy was actually intended to provoke war, ${ }^{104}$ and another openly characterized the bill, with or without reprisals, as a Fenian effort to force a third Anglo-American war. ${ }^{105}$ Of course, there were also senators who supported the reprisal bill, including at least one who had little objection to war with England. ${ }^{196}$

Senator Williams shared the prevailing distaste for the reprisal clause and explained that his own version would rule out reprisals by restricting the President to "means not amounting to acts of war."197 But he also had other objections to the House bill. First, it appeared to protect only naturalized citizens: its extreme remedies were not authorized unless a foreign government arrested a citizen upon an assertion of perpetual allegiance. ${ }^{188}$ Second, the bill merely empowered the President to take certain actions. It did not require him to do anything at all. ${ }^{199}$ Senator Williams attributed the current plight of imprisoned Americans to the Johnson administration's inattention, and he insisted that only a statute imposing on the executive an affirmative duty to act would satisfy the legislature's responsibility. ${ }^{200}$

4359,4445 (Williams amendment). Unsuccessful candidates appeared as well.

180 Id. at 4234 (remarks of Sen. Morton).

${ }^{191} I d$. at 4330 (remarks of Sen. Sumner) ("[I]t is a proposal of unutterable barbarism, which if adopted would disgrace this country.").

102 Id. at 4211 (remarks of Sen. Howard).

${ }^{105}$ Id. at 4329 (remarks of Sen. Buckalew).

${ }^{104}$ Id. at 4234 (remarks of Sen. Morton) ("[I]f it is desirable to get up a war between this country and any great Power I cannot conceive of a better plan of accomplishing that object than this.").

${ }^{105}$ Id. at 4446 (remarks of Sen. Howard after second adoption of the Williams amendment) ("I am not willing to pervert the character of our own Government, in obsequiousness to this demand of the Fenian organizations, whose sole ambition is, and always has been, to involve the United States in a war with Great Britain on account of their cause.").

196 Id. at 4237 (remarks of Sen. Stewart) (war would be no calamity); id. at 4350 (remarks of Sen. Sprague) (saying he would be glad to arm the merchant marine with letters of marque and reprisal).

${ }_{197}$ Id. at 4233,4359 . Senator Sumner, however, pointing out that Senator Conness had denied that reprisals were an act of war, viewed that language as too ambiguous to safeguard against them. Id. at 4331. He voted against Williams's amendment on every occasion until the final vote on the bill, from which he abstained.

${ }^{198}$ Id. at 4233,4237 . He may have been wrong, see supra note 156 , but the bill undeniably was at least ambiguous on the point.

${ }^{199}$ Cong. Globe, 40th Cong., 2d Sess. 4233-34 (1868).

200 Id. at $4233,4330$. 
The attempt to impose a required course of action on the President involved an inherent difficulty. ${ }^{201}$ If the bill were too specific, it would narrow the executive's options to the detriment of the imprisoned citizen; if the bill were too general, its vagueness would preclude any effective constraint on his discretion not to act. This tension was reflected in the criticisms levelled against the various suggested replacements for the reprisal clause.

The first concrete response to the Williams amendment was Senator Sumner's half-hearted proposal to substitute a duty to suspend diplomatic relations with the offending foreign power for Williams's broad language, whose ambiguity he deplored. ${ }^{202}$ This strategy was fleshed out by Senator Jacob Howard, who drafted an amendment requiring the President to demand the release of American citizens unlawfully detained by a foreign government and, in case of refusal, to cease diplomatic correspondence with its representatives. ${ }^{203}$ The Howard amendment enjoyed a brief vogue, but was criticized for specifying too narrowly the remedy and for depriving the imprisoned citizen of diplomatic support when he needed it most. 204

Another alternative was Senator Charles Buckalew's suggestion, which was also adopted for a time. ${ }^{205}$ This amendment was not intended to confer any new powers on the executive, but merely to clarify his duty to "exert all his powers under the Constitution and laws" on behalf of American citizens abroad. ${ }^{208}$ Senator Williams attacked this proposal for its failure to define the duty it imposed, ${ }^{207}$ but a more fatal objection was probably its refusal to

203 See id. at 4358 (remarks of Sen. Fessenden).

${ }^{202}$ Id. at 4331 ("The old law writers say that in these general terms lurketh much trouble. Why use these general terms that of themselves require definition?"). See supra note 197; infra note 218 and accompanying text.

${ }^{203}$ The amendment also either required or permitted the President to withdraw this country's diplomatic representative; Senator Howard apparently did not understand at first that his language was mandatory, and he later modified it. See Cong. Globs, 40th Cong., 2d Sess. 4358-59 (1868).

${ }^{204}$ See id. at 4352 (remarks of Sen. Fessenden); id. at 4355 (remarks of Sen. Conkling). The Howard amendment was adopted in the Committee of the Whole on July 23,1868, see id. at 4353 , and was replaced by the Williams amendment on the same day, see id. at 4359 .

${ }^{205}$ The Buckalew amendment was passed in the Committee of the Whole on July 23, 1868 , see id. at 4349 , and the Howard amendment was grafted onto it later that day, see id. at 4353 .

${ }^{208} \mathrm{Id}$. at 4349. The Buckalew amendment was in part a response to the claim that the Foreign Relations Committee's amendment had tied the President's hands by directing him to report to Congress, impliedly before taking further steps besides a demand. See id. at 4332 (remarks of Sen. Buckalew).

${ }^{207}$ Id. at 4333 ("What are his constitutional powers? Are the duties of the Executive to 
delegate any new powers to the President. ${ }^{208}$ A similarly weak version, proposed by Senator Orris Ferry, would have required the President to extend "every necessary means in accordance with the law of nations and the Constitution, treaties, and laws of the United States." ${ }^{208}$ Senator Conness ridiculed this language, ${ }^{210}$ and it was not even temporarily adopted. ${ }^{211}$

Senator Williams realized that his own amendment would be accused of the opposite fault, conferring too much discretionary power on the President. ${ }^{212}$ The bill did not require the executive to take extreme actions, but it did leave him a discretion that he might abuse. ${ }^{213}$ Senator Williams was impatient with exaggerated fears, however, and insisted that Congress must not be afraid to entrust the President with necessary powers. ${ }^{214}$ The executive should be free to adopt one policy to relieve a citizen imprisoned by England or France, and other policies for "the Barbary Powers" or "the islands of the ocean."215 Shortly before Senator Williams tried to meet his opponents' concerns by adding the language forbidding means "amounting to acts of war," he suggested an illustrative range of reasonable options among which the President should be free to choose:

$[\mathrm{H}] \mathrm{e}$ is left to exercise his judgment as the circumstances of the case may require in order to obtain the release of the American citizen who is wrongfully imprisoned in a foreign

be defined by law, or not?"). As Senator Conkling pointed out acidly in reply, however, this criticism applied equally to the Williams amendment. See id.; see also infra text accompanying note 217 .

${ }^{208}$ See Cong. Globe, 40th Cong., 2d Sess. 4332 (1868) (remarks of Sen. Buckalew) (amendment "will leave his whole constitutional power untouched, and it will simply be an admonition to him to act with energy to the full extent of his powers and report"); $i d$. at 4332-33 (remarks of Sen. Williams) (attacking Buckalew amendment); id. at 4349 (remarks of Sen. Conness) (amended bill "an insult to every naturalized citizen in the United States").

${ }^{20}$ Id. at 4353 . When asked to illustrate the means permitted by his amendment, Senator Ferry suggested suspension of diplomatic intercourse and "the power which has been exerted within the last few years by the fleets of this Government upon the coast of Japan." Id. at 4354. Presumably this alluded to the bombardment of the port of Shimonoseki by an allied fleet of Americe and the European powers in response to anti-foreign incidents. See 1 P. Treat, Diplomatic Relations Between the United States and Japan 214-44 (1932).

${ }^{210}$ Cong. Globe, 40th Cong., 2d Sess. 4353 (1868) (remarks of Sen. Conness); id. at 4354 (same).

${ }^{211}$ See id. at 4357 (Ferry amendment rejected 17-32).

212 Id. at 4233 (remarks of Sen. Williams).

${ }_{213}$ Id.

214 Id.

${ }^{215}$ Id. at 4359. 
country. He may resort to all the instrumentalities of diplomacy to accomplish that purpose. He may intimate to the foreign Government that the United States will regard its acts as violative of international law, and will not submit to outrages upon the rights of its citizens; and such an intimation coming from the Executive of the nation under a law of this description will have power, will produce influence, and in many cases, I venture to say, it will result in the release of the person imprisoned.

... [I]t is not to be presumed that the Executive will violate the law of nations or undertake to exercise any of the dangerous powers that are now specifically conferred upon him by the bill. But, sir, he may negotiate for the release of an American citizen imprisoned in a foreign country. He may use all the influences that he can to secure his restoration to liberty; and cases may arise where it would be the duty of the Executive of the nation, and where he ought to have the power at once, without any delay, to wrest an American citizen from the clutches of a despot in a foreign country. I can imagine many cases where the Executive should be invested with the power at once to proceed and vindicate the rights of American citizenship upon foreign soil by all the power of the nation. $^{216}$

The explanation did not satisfy Senator Roscoe Conkling, who criticized Williams for using "language unknown to the legislative phraseology with which we are familiar" without providing a definition:

I can suppose, if it were worthwhile, a hundred illustrations, confessedly not amounting to acts of war, and in a certain sense adapted to this purpose, which nobody would pretend for one moment the President had a right to do unless he was armed by legislative authority with the powers. Suppose, for example, the President should take it into his head to send abroad embassadors under the name of commissioners, as one President in one instance asserted the right to do. Suppose he

216 Id. at 4233 . Compare id. at 4330 (formal motion to amend) with id. at 4232 (original version without the exception for acts of war). The wresting and vindicating that conclude the passage quoted above may not validly illustrate the power conferred by the amendment after the exception was added. 
should send strolling groups or strolling individuals over to Europe to conduct side-bar negotiations. Suppose he should expend moneys otherwise in such modes as he might think are conducive to the harmony of nations and the establishment of the rights of American citizenship. They would not be acts of war, and yet they would fall within the spirit and within the letter of the amendment of the honorable Senator from Oregon. $^{217}$

It would have greatly simplified the analysis of the legislative history if Senator Williams had replied to this challenge, or if the opponents of the measure had raised some other objection to the discretion it conferred besides the likelihood that it would permit reprisals or lead to war. ${ }^{218}$

Expanding the scope of the remedial section from the rights of naturalized citizens to the rights of all citizens, though uncontroversial, raised further questions of definition. Because the President's duty would be triggered by events other than an assertion of the doctrine of perpetual allegiance, it would become necessary to decide what constituted a "wrongful" detention "in violation of the rights of American citizenship." In his first discussion of the amendment, Senator Williams explained that the President

shall proceed at once and investigate the facts of the case, and he shall ascertain whether that imprisonment is rightful or wrongful, whether or not it violates the rights of American citizenship; and if he ascertains that the imprisonment is unjust and unfounded, that it is made upon some frivolous pretext, that it is made for some alleged political opinion which the party entertains to which that government does not give its sanction, that he shall proceed upon ascertaining the facts and demand the release of that citizen so imprisoned . . . 218

This account appears to have satisfied his fellow Senators, who adopted Williams's amendment without debating the point. ${ }^{220}$

317 Id. at 4333.

${ }^{218}$ See id. at 4331 (remarks of Sen. Sumner); id. at 4359 (remarks of Sen. Howard). This was also Senator Williams's explanation for opposition to his amendment. See id. at $4233,4332-33$.

210 Id. at 4233.

${ }^{220}$ Senator Howard, when asked to explain similar language in his own amendment ("unlawfully arrested or unlawfully detained by any foreign government"), had explained "that the only practical construction to be given to that word 'unlawful' would be this: that the arrest and detention must be contrary to the laws of nations, contrary to the rights of an 
After its long week's work, the Senate passed the bill as amended on July 25,1868 , with only five dissenting votes. ${ }^{221}$ The House concurred in the amendments on the same day, ${ }^{222}$ and the bill for the protection of citizens in foreign states, shorn of its reprisal provision, became law on July $27 .{ }^{223}$

\section{Conclusions from the Legislative History}

The legislative history of the Citizens in Foreign States Act casts a considerable amount of light into some of the darker corners of the statutory language. Section 3 was adopted as a floor amendment in the Senate, and its remedial grant of power represented a compromise position between the belligerent reprisal provision of the House bill and the essentially declaratory approach favored by Senator Sumner and his committee. Because the Williams amendment was one of several proposals and was accepted by the House without debate, only a limited portion of the legislative history directly addresses its wording. But most of the debate in the Senate, and a good deal of the debate in the House as well, focused on the choice among alternatives to the reprisal provision, so that the range of appropriate presidential options was explored thoroughly enough to illuminate the grant of power finally enacted.

The legislative history does not provide unambiguous answers to all questions concerning the statute; no legislative history ever does. Much of the debate on the Act is particularly unhelpful because public passions were so inflamed that politicians were tempted to indulge in oratory and posturing, often displaying their patriotic fervor rather than addressing the differing merits of specific proposals offered to remedy the problem that was universally perceived. Their awareness of sharply focused public attention may explain why the senators took the context of the debate so thoroughly for granted and did not trouble to examine the consequences of alternative wordings in situations not then before

American citizen under the laws of nations." Id. at 4359 . His answer was equally unproductive of further discussion.

221 Id. at 4446. Twenty senators, however, including Buckalew, Sumner, and Trumbull, did not vote at all. The Senate also struck from the preamble the words "for the protection of which the Government of the United States was established." Id. at 4445.

2x2 Id. at 4474 .

223 Act of July 27,1868 , ch. 249,15 Stat. 223 (codified in part at 22 U.S.C. \& 1731 (1976)). The pro-Fenian press was enraged by the mildness of the bill. See W. D'ArcY, supra note 72 , at 300 . 
them. ${ }^{224}$ In such circumstances, stretching the statute to the limits of its language poses an unusual danger of achieving wholly unintended results.

Nonetheless, three basic propositions emerge rather clearly from a reading of the congressional debates. First, the Senate deliberately expanded the third section beyond the scope designed by the House, which had concentrated on incidents involving naturalized citizens. Second, the legislature not only imposed a duty on the President, but also intended to grant him powers commensurate with that duty. Finally, when Congress instructed the President to utilize "such means, not amounting to acts of war, as he may think necessary and proper to obtain or effectuate such release," it was thinking in terms of diplomatic actions and military or economic sanctions designed to affect the conduct of the offending foreign nation.

1. "Wrongful" Detention. The first point is unmistakable. The House bill applied only to arrests based on an allegation of perpetual allegiance to the native sovereign, or at least it was too susceptible to that interpretation. ${ }^{225}$ Senator Williams objected to

224 The Citizens in Foreign States Act is a vivid illustration of the strengths and weaknesses of floor amendments. They may spark discussion that elucidates the meaning of ambiguous statutory language rather than leaving the language to be blandly restated in a committee report, thus providing a useful extrinsic aid to interpretation. See 2A J. SuTHERLand, Statutes and Statutory Construction $\$ 48.14$ (C. Sands rev. ed. 1973). Floor amendments are frequently thrown together on the spot, however, and the clumsy drafting that results may obscure rather than clarify the legislative purpose. See Hernstadt v. FCC, No. 80-2228, slip op. at 13-17 (D.C. Cir. Oct. 18, 1980); W. KeEfE \& M. OguL, The American Legislative Process: Congress and the States 243-44 (4th ed. 1977).

${ }^{225}$ An argument for reading section 2 of the House bill narrowly may be stated briefly as follows. The bill as first reported empowered reprisals

whenever it shall be duly made known to the President that any naturalized citizen ... has been arrested ... upon the allegation that naturalization . . . does not operate to dissolve his allegiance to his native sovereign . . . , or if any citizen shall have been so arrested . . . whose release upon demand shall have been unreasonably delayed or refused.

H.R. 584, § 2, Cong. Grobe, 40th Cong., 2d Sess. 783 (1868) (emphasis added). Both clauses restricted the scope of the bill to arrests based upon an allegation of perpetual allegiance. The difference between the two clauses was that the first authorized reprisals in case of future arrests as soon as they were made known, but reprisals for past arrests only after a demand. After recommittal, the committee struck the words "naturalized" and "so" emphasized above, but left that section of the bill otherwise intact. The only expansion in the scope of the first clause would be to the case of a native citizen mistaken for a naturalized one; the real explanation for this change is probably the objection that it was insulting to keep repeating the words "naturalized citizen" unnecessarily. See Cong. GLOBE, 40th Cong., 2d Sess. 1106 (1868) (remarks of Rep. Clarke). If the structure of the section was being preserved, the second clause should still be concerned with past arrests, and the word "so" might be considered redundant in context. If the second clause were intended to apply to 
this preference for naturalized citizens and drafted a substitute covering the arrest of any citizen, as long as it was "wrongful and in violation of the rights of American citizenship." ${ }^{226}$ This language would include detentions that were "unjust and unfounded, . . . made upon some frivolous pretext, [or] made for some alleged political opinion.",227

Senator Williams did not criticize the House bill for extending too much protection to naturalized citizens, and his discussion of the relationship between the House provision and his own alternatives implies that he included cases of discrimination against naturalized Americans among the violations of the rights of citizenship. ${ }^{228}$ The prominence of the mixed jury issue in the naturalization controversy demonstrates that Congress was willing to regard even procedural defects as impairing the fairness of a citizen's imprisonment, ${ }^{228}$ and the Williams amendment could not

any citizen arrested without limitation as to the reason alleged, it would authorize the President to take reprisals for perfectly justified and lawful arrests, a possibility that the committee originally opposed so firmly that it included an inartfully drafted exception clause in the bill. See id. at 832 (remarks of Rep. Banks); id. at 1099 (remarks of Reps. Cook and Banks); id. at 970 (remarks of Rep. Judd). See also id. at 4233 (argument of Sen. Williams based on retention of words "such foreign government").

${ }^{228}$ See supra notes 198,219 , and accompanying text. Senator Williams appeared to regard "wrongful" and "in violation of American citizenship" as fairly equivalent, joining them sometimes by an "or," sometimes by an "and," and sometimes allowing "wrongful" to stand for both. See Cong. Globe, 40th Cong., 2d Sess. 4233, 4330, 4332 (1868). In parsing the words of the statute, it seems most reasonable to regard "in violation of the rights of American citizenship" as specifying a particular kind of "wrongfulness," rather than to view the two as independent requirements, even though this approach renders the word "wrongful" largely redundant.

The statute also requires that the detention appear to be "unjust" before the President is obliged to inquire into the reasons; Senator Williams himself saw no need for this, and no other senator explained it or spoke in its favor. See id. at 4330 . Given its role in the statute as a threshold requirement, this provision is probably best construed by defining "unjust" as "reasonably likely to turn out, on further investigation, to be "wrongful and in violation of the rights of American citizenship." "

${ }^{227}$ Id. at 4233; see supra text accompanying note 219.

${ }^{228}$ See Cong. Globe, 40th Cong., 2d Sess. 4233 (1868). Senator Lot Morrill of Maine explicitly stated this interpretation of Williams's language and was not contradicted. See id. at 4357.

239 See id. at 970 (remarks of Rep. Judd) (criticizing crime exception in original House bill):

From the language of it the United States is forbidden to see that foreign laws are justly administered when a citizen is charged with crime in a foreign land. Can it be that we are to pass a bill justifying Great Britain in her recent refusal to allow our citizens the benefit of the laws as they stand upon her statute-book?

See id. at 4354 (remarks of Sen. Conness) (concerning denial of mixed jury at Warren's trial). Indeed, after Colonel Nagle's confession and apology demonstrated the true nature of the Erin's Hope expedition, see supra text accompanying note 92 , the only possible objec- 
have been intended to exclude these notorious cases sub silentio. Williams was therefore illustrating the additional cases that his language would embrace when he spoke of imprisonments that were "unfounded" or "made upon some frivolous pretext." The statutory language includes both the unfounded arrest of any American citizen and the technical discrimination against naturalized citizens.

2. Duty or Delegation. Representative Banks presumably considered his reprisal provision an excellent contribution to the cause of American Fenians imprisoned by the British. Nonetheless, Senator Williams viewed the House bill as wholly inadequate and convinced the Senate that it should not be satisfied with a bill by which "the President is 'empowered' to do certain things[,] but he is not required to do anything."230 All the amendments proposed in the Senate thereafter phrased the remedial provision in terms of a duty imposed on the President to perform certain actions, ${ }^{291}$ though some of these duties were so broadly worded that they might effectively confer a discretion not to act. ${ }^{232}$ Some of the proponents recognized that their amendments would merely make mandatory the exercise of authority that the President already possessed. ${ }^{23 s}$

The adoption of the Williams amendment, however, was a victory both for the principle of imposing a duty on the executive and for the principle of granting further authority. This fact is most clearly demonstrated in the ultimate replacement of the Buckalew amendment-which would have clarified the President's duty

tions to Warren's detention were the technical ones.

${ }^{230}$ Cong. Globe, 40th Cong., 2d Sess. 4233 (1868).

231 See supra text accompanying notes 202-09 (proposals of Sens. Sumner, Howard, Buckalew, and Ferry).

${ }^{232}$ See supra text accompanying notes 205-09 (amendments of Sens. Buckalew and

Ferry). The same, of course, could be said of the Williams amendment.

2s3 See, e.g., Cong. Globe, 40th Cong., 2d Sess. 4331 (1868):

Mr. SUMNER: The clause as it stands is:

The President shall forthwith demand the release of such citizen, and if the release so demanded be unreasonably delayed or refused it shall be the duty of the President, \&c.

Then I propose to say:

To suspend diplomatic relations with such foreign Power.

Mr. FESSENDEN: He has that power now.

Mr. SUMNER: Unquestionably he has that power now.

Similarly, the Buckalew amendment was intended solely to impose a duty on the President to exercise powers he already possessed, and not to grant an iota of further authority. See supra text accompanying note 206. 
while leaving him to carry it out only with the powers he already possessed-by the language that Senator Williams had stressed as entrusting the President with new discretionary powers. ${ }^{234}$

3. Extent of the Power Delegated. A few members of Congress analyzed in general terms the range of possible strategies for vindicating the rights of an American citizen imprisoned abroad. Representative Banks, reporting his reprisal bill for the second time, stressed that the general principles stated in the first two sections of the bill

must be accompanied by some principle or power which will be able to produce an effect upon the legislation of other countries or the action of other Governments in reference to the rights of our naturalized citizens.

What are the powers necessary to affect legislation? They are: first, negotiation; second, remonstrance; third, arbitration; fourth, compromise; fifth, non-intercourse; sixth, embargo; seventh, retaliation; eighth, general reprisal; and ninth, war. These are the only powers by which we can impress or influence the Governments of other nations in regard to the recognition of the rights which we claim and assert on behalf of our citizens. $^{235}$

Representative Godlove Orth, a member of Banks's committee, saw fewer possibilities, but of a similar sort.

This is not a law enacted by the legislative branch of the Government, and is not intended to operate upon our citizens in their individual capacity or merely to affect individual rights. Not at all. We are declaring to-day in the face of the civilized world what is our settled principle on this subject, and giving notice of the means we intend to use in enforcing that law against every nation that violates its provisions. We could accomplish our object by a declaration of war. But is this House prepared to take that as the first step? You can do it by declaring non-intercourse. Is this House prepared even to adopt that course? I think not. What other resort is left to you but reprisal, a principle of action recognized by nations since the

234 See Cong. Globe, 40th Cong., 2d Sess. 4349 (1868) (remarks of Sen. Stewart on Buckalew amendment); id. at 4356 (remarks of Sen. Morrill on Buckalew amendment); id. at 4233 (remarks of Sen. Williams on his amendment); supra text accompanying notes 212 16.

${ }^{23 s}$ Cong. GroBe, 40th Cong., 2d Sess. 1798 (1868). 
earliest dawn of civilization.

.... We want to go before Europe not in the garb of diplomacy, but in the might and strength and power of this great Republic, and in doing so we will be respected. ${ }^{236}$

And Senator James Doolittle, speaking in support of the Williams amendment, expressed the same range of options more succinctly: "In foreign countries those rights are to be secured either by diplomacy or by arms."237

More frequently, the speakers indicated their notions of appropriate action by example, always remaining within the range of diplomatic, military, and economic responses. The specific alternatives proposed for the reprisal provision in both the House and the Senate all fell within this sphere of action. Representatives offered as possible sanctions suspending commercial relations or all diplomatic and commercial intercourse; blockading ports and further reprisals on the high seas; interposing with "promptitude and energy" on behalf of imprisoned Americans; and labelling the offense just cause for war or incompatible with friendly relations. ${ }^{238}$ Senators Sumner and Howard suggested suspension of diplomatic relations, and Senator Ferry illustrated his vaguely worded substitute with that same response plus military action. ${ }^{238}$ Senator Conness, leading the pro-Fenian forces in the Senate, was content to arm the President with a more immediate reprisal clause. ${ }^{240}$ Senator Williams's own description of the powers his amendment would confer and their assuredly peaceful effect has already been quoted. He spoke of resorting to "all the instrumentalities of diplomacy," to an "intimation" that the United States would not "submit to outrages," and to the President's negotiating and using "all the influences he can"; he also mentioned, at a time before the addition of the exception concerning acts of war, proceeding "to wrest an American citizen from the clutches of a despot."241

Most Senators saw no new threats to the structure of govern-

236 Id. at 1103.

${ }^{237}$ Id. at 4446. Senator Doolittle was a late convert to the Williams amendment. He "could have preferred different language," and he agreed that a partial war-making power was entrusted to the executive "to a certain extent," but believed that the bill was not an unconsitutional delegation of power. Id.

2ss See supra text accompanying notes 150-67.

239 See supra text accompanying notes 202-03; supra note 209.

240 See supra notes $175,187$.

${ }^{241}$ See supra note 216 and accompanying text. 
ment in the Williams amendment. In fact, Williams's references to negotiation and to "instrumentalities of diplomacy" implicated authority that the Senate had assumed the President already possessed, such as the power to negotiate ${ }^{242}$ and the power to suspend diplomatic relations. ${ }^{243}$. When its opponents complained of the "broad and dangerous discretion" that the Williams amendment would place in the hands of the President, ${ }^{244}$ they were raising objections much like those that led to the rejection of the House bill-the Williams amendment could be construed to authorize that same barbarism, the reprisal arrest, ${ }^{24 s}$ and would permit the President to perform further preliminary acts of hostility whose inevitable tendency would be to precipitate war, even if those acts did not technically come within the ban of the proviso. ${ }^{216}$ This preoccupation with the risk that war would result from the President's actions was reasonable, for some of the bill's supporters were openly acknowledging their readiness for war with England. Only Senator Conkling warned that Williams's vague language might empower the President to employ means quite unlike those Congress had contemplated, and the sole examples he gave were of foolish and peculiar pseudodiplomatic endeavors. ${ }^{247}$

In sum, not even Andrew Johnson's bitterest opponents in the Senate expressed the fear that the bill might give him new powers on the domestic front, or authorize him to placate England by taking stricter measures against the "Fenian conspiracy" in America. None of the legislators contemplated circuitous measures for obtaining a citizen's release that might require arming the President with dangerous domestic authority. Rather, the only peril they saw was in the foreign country's reaction to the means the President chose to employ against it: direct means for backing up the na-

242 See, e.g., Cong. GloBe, 40th Cong., 2d Sess. 4211 (1868) (remarks of Sen. Howard) ("I hope, therefore, that the third section will be entirely stricken out, leaving the whole subject where it properly belongs, as a subject of negotiation between our own and foreign Governments to be conducted under the supervision of the President through our proper diplomatic agents abroad."); id. at 4349 (remarks of Sen. Stewart on the Buckalew amendment) ("The amendment of the Senator from Pennsylvania, as adopted, amounts simply to this: that the President may negotiate and he may report to Congress. He has power to do that now.").

${ }^{243}$ See supra note 233.

244 See ConG. GLOBE, 40th Cong., 2d Sess. 4359 (1868) (remarks of Sen. Howard).

215 See id. at 4445 (remarks of Sen. Howard); supra note 73.

24 See Cong. Globe, 40th Cong., 2d Sess. 4359 (1868) (remarks of Sen. Howard); id. at 4233 (remarks of Sen. Williams).

${ }^{217}$ See supra text accompanying note 217. 
tion's demand and obtaining the release of its citizens.

The legislative history thus demonstrates that the Fortieth Congress intended its delegation of authority to be used against foreign nations that had wrongfully imprisoned American citizens. The Williams amendment was a compromise that brought a bill for the protection of citizens through the Senate without a reprisal provision. After debating a range of options in diplomacy and force, the legislature denied the President the more extreme powers favored by the supporters of the Fenians and gave him instead the flexibility to choose among those options himself. The means "necessary and proper to obtain or effectuate such release" contemplated by Congress were measures bringing pressure and influence to bear on an offending foreign government. None of the legislators contemplated enhancing the President's power to deal adversely with American citizens, their rights, or their claims.

\section{Construction of the Statute}

We may now combine the insights provided by the legislative history with other sources of legal perspective on the statute to determine the purpose and limits of section 1732, and we may do so free of the immediate press of the Iranian hostages episode and the litigation that ensued. Any temptation to stretch the reach of the statute to buttress an accomodating view of the President's fait accompli in the Iranian counterpart to the Fenian crisis has been eliminated by the Supreme Court's decision in Dames \& Moore v. Regan. ${ }^{248}$

The first element in the statutory language that must be confronted is the description of an imprisonment as "wrongful and in violation of the rights of American citizenship."249 It is clear that this language is not limited to incidents of hostage-taking. Whether it includes all seizures of hostages by foreign governments was a question that gave the Supreme Court pause in Dames \& Moore. As Justice Rehnquist observed, "[a]lthough the Iranian hostage-taking violated international law and common decency, the hostages were not seized out of any refusal to recognize their American citizenship-they were seized precisely because of their

248101 S. Ct. 2972, 2985 (1981).

240 It appears most reasonable to regard detentions "in violation of the rights of American citizenship" as a lesser included category among "wrongful" detentions, on the basis of both common sense and the legislative history. See supra note 226. 
American citizenship."250 Nonetheless, the history of the Williams amendment shows unequivocally that it was intended to broaden the coverage of the Act beyond foreign actions denying the efficacy of American naturalization, and Senator Williams's own description of his intent included arrests that were "unfounded" or "made upon some frivolous pretext."281

If the statutory language subsumes both the unfounded arrest of any American citizen and the calculated discrimination against naturalized citizens, the phrase "rights of American citizenship" can be given a simple conceptual definition. A principle of modern international law requires each state to accord aliens a minimal level of substantive justice and procedural fairness, even when the state denies these to its own nationals. ${ }^{252}$ Transgression of these minimum standards is a violation, and functionally a denial, of rights of alien citizenship. The two categories of violation contemplated by the Citizens in Foreign States Act thus coalesce: the offense consists in denying an American citizen rights or privileges that international law, ${ }^{258}$ a treaty, or the state's own law ${ }^{254}$ guarantees to American citizens or to aliens generally, and in treating the American citizen as badly as the state might be permitted to treat one of its own citizens. This construction of the language comports well with the legislative history by allowing the Act to reach all the situations actually discussed by Congress and gives a logical legal content to the wording.

The next problem is to determine whether the statute imposes a mandatory duty on the President and, if so, whether he receives an accompanying delegation of power for the purpose of fulfilling that duty. Under the usual methods of statutory interpretation, the language of the Act strongly suggests an obligation and a parallel grant; ${ }^{288}$ the legislative history confirms this impression on both

250 $101 \mathrm{~S}$. Ct. at 2985 (emphasis in original) (quoted more fully supra note 29).

251 See supra text accompanying note 227.

${ }^{232}$ See, e.g., Restatement (Second) of the Forgign RgLations Law of the Untrib STATES $§ \S 169,182-186$ (1965).

2ss It may be recalled that Senator Howard defined an "unlawful" detention for purposes of his own amendment as one "contrary to the rights of an American citizen under the laws of nations." See supra note 220.

254 A prominent example of a privilege that the state's own law accords to aliens generally would be the British jury de mediatate linguae, whose role in the genesis of the statute has been somewhat obsessively reiterated above. See supra notes 91-92, 115, and accompanying text. For the argument that Congress intended to secure for Americans the benefit even of technical procedural defenses to prosecution, see supra note 229.

${ }^{265}$ The statute declares that under certain circumstances "it shall be the duty of the 
counts. Senator Williams was emphatic about the need to impose a duty on the executive and about the inadequacy of a bill that would merely empower him to act if he so desired, ${ }^{258}$ and the Senate's concurrence with Williams in defeating the Buckalew amendment demonstrates the congressional desire to augment the President's powers. ${ }^{257}$

Of course, the fact that Congress in 1868 believed that it was delegating an authority not already possessed by the President does not in itself suffice to prove that the legislative intent extended to powers beyond the scope of a present-day conception of inherent executive authority. ${ }^{258}$ Opinions regarding the amount of independent power conferred by article II of the Constitution have varied over time, and it is possible that a narrow view of presidential foreign relations power held by the Fortieth Congress made it appear necessary to enact an express legislative consent to courses of action that would today be regarded as among the options normally available to a President acting on his own authority. ${ }^{259}$

President" to demand the reasons for imprisonment; if it then appears (to the President, presumably) that the imprisonment is "wrongful" in the appropriate sense, "the President shall forthwith demand" release of the citizen; and if the release is then delayed or refused, "it shall be the duty of the President" to take certain further measures. Act of July 27, 1868, ch. 249, § 3, 15 Stat. 223, 224 (codified at 22 U.S.C. $\$ 1732$ (1976)) (emphasis added); see supra text accompanying note 39 . Such language is presumed to be mandatory unless other factors require an opposite conclusion. See, e.g., Escoe v. Zerbst, 295 U.S. 490, 493 (1935); Association of Am. R.Rs. v. Costle, 562 F.2d 1310, 1312 (D.C. Cir. 1977).

${ }^{2 s 8}$ See supra notes $199-200$ and accompanying text. Whether that duty is enforceable by means other than political pressure is another question, one on which the legislative history is totally silent. A presidential duty to use such means "as he may think necessary and proper" is an unlikely candidate for judicial enforcement, see Redpath v. Kissinger, 415 F. Supp. 566, 568 (W.D. Tex.) (mandamus will not lie to enforce 22 U.S.C. $\$ 1732$ ), aff'd mem., 545 F.2d 167 (5th Cir. 1976), or even justiciability, see Coleman v. Miller, 307 U.S. 433, 453-54 (1939) (absence of judicially manageable standards for decision). The duty to "forthwith demand the release of such citizen" if the imprisonment "appears to be wrongful and in violation of the rights of American citizenship" is more susceptible to judicial review, but given the lack of an explicit cause of action and the judicial insecurity about dictating foreign policy, a court might be likely to read back into the statute the discretion that Senator Williams thought he had excluded, or to view any complaint as raising a nonjusticiable political question. See Chicago \& S. Airlines v. Waterman S.S. Corp., 333 U.S. 103, 111-12 (1948).

${ }^{257}$ See supra text accompanying note 234 .

${ }^{258}$ The Fortieth Congress took, for example, a notoriously narrow view of President Johnson's constitutional authority over executive appointments. See, e.g., R. BERGER, IMpeachment: The Constitutional Problems 280-85 (1973) (on constitutionality of the Tenure of Office Act).

${ }^{259}$ In addition, Senator Ferry expressed a concern that the President himself might take too limited a view of his authority in dealing with Great Britain unless the statute were passed. Cong. GloBe, 40th Cong., 2d Sess. 4353 (1868). 
The most difficult question in interpreting the statute, however, is the intended scope of the phrase "such means, not amounting to acts of war, as he may think necessary and proper to obtain or effectuate such release." An easy solution would be to ignore the problem altogether and to construe the statute as granting the President almost total discretion to determine whether an act he wished to perform was a "means" to obtain release, as well as whether it was necessary and proper. Rather than being limited to direct methods of interaction with foreign governments, the statute might authorize the President to engage in any conduct that bore a rational relationship to the goal of gaining freedom for American citizens. ${ }^{260}$ Taking the word in its broadest possible meaning, a court might claim that the Act spoke plainly and distinctly, so that no recourse to ancillary principles of statutory interpretation or to evidence in the legislative history was permissible. But the paramount goal of statutory interpretation is to effectuate the intent of Congress, and a brief consideration of the statute and the range of its conceivable applications demonstrates that an assumption that the sweeping generality of the language speaks for itself would create a serious risk of stretching the statute far beyond the legislative design.

Many presidential measures rationally related to freeing imprisoned Americans might transgress constitutional and statutory limits on executive action. If the President agreed to pay a sizable ransom for release of Americans, would the statute empower him to seize private property to raise the ransom? ${ }^{261}$ Would it empower him to levy a tax to raise the ransom? ${ }^{262}$ Would it empower him to

${ }^{280}$ See Brief for Respondent, Dames \& Moore v. Regan, 101 S. Ct. 2972 (1981), at 52 ("Section 1732 delegates to the President all powers that bear a 'reasonable relation to the particular emergency confronted." ") (quoting United States v. Yoshida Int'l, Inc., 526 F.2d 560, 579 (C.C.P.A. 1975)). The government's sweeping claims concerning the power granted by the statute inspired a certain amount of humor from the bench during oral argument. See, e.g., 49 U.S.L.W. 3961 (U.S. June 30, 1981) (discussion of President's power to send Solicitor General Rex Lee to Tehran as substitute hostage).

261 This, of course, was the plaintiffs' interpretation of the presidential action in the Iranian cases. See, e.g., Brief for Petitioner, Dames \& Moore v. Regan, 101 S. Ct. 2972 (1981), at 34-35; Marschalk Co. v. Iran Nat'l Airlines, 518 F. Supp. 69, 88 (S.D.N.Y.), rev'd, 657 F.2d 3 (2d Cir. 1981). The government, on the other hand, has insisted that no ransom was paid. See, e.g., The Iran Agreement: Hearings before the Senate Foreign Relations Comm., 97th Cong., 1st Sess. 28 (1981) (statement of former Deputy Secretary of State Christopher). The Supreme Court left the takings question in Dames \& Moore for eventual resolution in the Court of Claims. See supra note 22.

${ }^{262}$ The levying of taxes is a legislative function, though a properly drafted delegation of authority may empower the executive to set amounts or to impose an exaction for regulatory 
discontinue other government programs and reroute their funding into payment of the ransom? ${ }^{263}$ Certainly the statute would not be read as authorizing violations of constitutional rights, ${ }^{284}$ and a court would only permit the breadth of the statutory language to prevail over prior inconsistent legislation after a close inquiry into the legislative intent. ${ }^{265}$

Even where the commands of the Bill of Rights and explicit contrary legislation were not violated, allowing the President absolute discretion to define and to choose the "means" of action would confer almost limitless power. Suppose the President forbade Americans to travel to Ireland, in the hope of conciliating England and obtaining freedom for detained citizens. ${ }^{286}$ Would that be a "means" to obtain release? Suppose, with the same motive, he prohibited interstate commerce in textiles of non-British manufacture. Does the statute delegate to him all powers possessed by Congress in all fields, both at home and abroad, so that he could singlehandedly enact by regulation any program of domestic legislation he believed might help appease a foreign state and contribute to the release of American citizens? Finally, suppose the President concluded that only a credible threat of war would suffice to free Americans imprisoned in a foreign country and that it would be years before the United States was militarily strong enough to intimidate the adversary. Would the statute authorize him to resurrect the draft and to promulgate regulations channelling private

purposes. See Federal Energy Admin. v. Algonquin SNG, Inc., 426 U.S. 548, 559 \& n.10 (1976) (upholding presidential power to assess import license fees under delegated authority to "adjust imports of" articles impairing national security); National Cable Television Ass'n v. United States, 415 U.S. 336, 340-42 (1974) (narrowly construing delegation to agency of authority to assess fees, to avoid constitutional question).

${ }^{283}$ Cf. United States v. MacCollom, 426 U.S. 317, 321 (1976) (Rehnquist, J.) (plurality opinion) ("The established rule is that the expenditure of public funds is proper only when authorized by Congress, not that public funds may be expended unless prohibited by Congress."); 31 U.S.C. $\$ \S 1400-1407$ (1976) (impoundment control legislation).

${ }^{204}$ See American Int'l Group, Inc. v. Islamic Republic of Iran, 657 F.2d 430, 451 (D.C. Cir. 1981) (statement of McGowan, J.); Narenji v. Civiletti, 481 F. Supp. 1132, 1141 n.7 (D.D.C.), rev'd on other grounds, 617 F.2d 745 (D.C. Cir. 1979), cert. denied, 446 U.S. 957 (1980).

2es See, e.g., Morton v. Mancari, 417 U.S. 535, 549-51 (1974) ("[W]hen two statutes are capable of coexistence, it is the duty of the courts, absent a clearly expressed congressional intention to the contrary, to regard each as effective.").

${ }^{286}$ It is worthwhile recalling that section 1732 was cited in Zemel v. Rusk, 381 U.S. 1, 15 (1965), not as a source of authority for travel restrictions, but as imposing a responsibility on the President that made reasonable his attempts to control travel to Cuba, and that section 1732 played no role in the Supreme Court's recent decision in Haig v. Agee, $101 \mathrm{~S}$. Ct. 2766 (1981). 
investment into defense industries as a prelude to obtaining the release of citizens?

Returning from these extravagant possibilities to the language of the Act itself, we may observe that section 1732 demonstrates a legislative desire, not to abandon imprisonment crises into the President's hands, but to intrude upon his procedures for handling them. ${ }^{267}$ The statute constrains the President first to demand reasons for the imprisonment of American citizens, and then to demand their release. If release is refused or delayed, he is required to use means to obtain it and to report his actions promptly to Congress. The Act appears to contemplate a series of transactions between the President and the foreign government, ${ }^{268}$ leaving him room for discretion, but subject to oversight by Congress. The statute is thus susceptible to other, far narrower interpretations. For example, it might be concluded that initial diplomatic or quasimilitary actions constituting direct means of obtaining release should be employed by the President forthwith, but that Congress must be consulted "as soon as may be practicable," and that less direct measures having greater domestic consequences and allowing more time for consideration will require legislative approval. ${ }^{289}$

It is true that courts are more tolerant of broad delegations of power in the foreign relations area, ${ }^{270}$ but the full language of section 1732 raises serious doubts whether an open-ended delegation was ever intended. The total obscurity of the statute for over a century is a further indication that the words may have possessed a significance to its framers that is not immediately apparent today. Given all of these factors, it would be hasty to assume that the Act issues a blank check to the President, without first examin-

${ }^{267}$ As demonstrated supra part III-B, the legislative history fully bears out this suggestion of the statutory language.

288 The proviso "not amounting to acts of war" further supports the observation that Congress was contemplating actions directed against a foreign state or its citizens. Obviously, actions directed against our own citizens csuld not "amount[] to acts of war" in any sense.

${ }^{288}$ This is not, however, the precise interpretation favored by the authors. See infra text accompanying notes $279-81$.

${ }^{270}$ See United States v. Curtiss-Wright Export Corp., 299 U.S. 304, 320 (1936). That case does not support, however, a notion that delegations of power in the foreign relations area should be broadly interpreted; the statute at issue, which empowered the President to curb classes of arms sales to certain belligerents in South America if the prohibition would contribute to peace in the area, may have expressed somewhat vaguely the conditions for the exercise of power, but it could not have been more explicit as to the actual power delegated. 
ing the legislative history.

Once it is recognized that the legislative history is a legitimate aid to construction of the statute, the argument for the broadest possible reading is easily refuted. Congress passed the Citizens in Foreign States Act during a period of nationalistic indignation and self-assertion. The reprisal provision was intended to force the President into a more belligerent posture towards Great Britain, ${ }^{271}$ and Senator Williams designed his amendment to permit the executive to adopt a variety of strategies for bringing pressure to bear without necessarily provoking war. ${ }^{272}$ The "means" authorized by the statute were direct courses of action against a foreign government through diplomatic, military, and economic channels. Given the tenor of the public controversy, it was evident that the means at issue were to be directed against offending foreign governments, and Congress could not be expected to anticipate that a century of total obscurity would wrench the language from its context and leave the Act so poorly focused that it could be turned as a weapon against American citizens at the request of foreign captors. ${ }^{273}$ Fortunately, the legislative history is well-documented, and the limits of the congressional intent emerge rather clearly from a reading of the debates.

The statute does not support the bootstrap argument that the diplomatic powers conferred by the Act include the power to enter into executive agreements with a foreign state and that through such agreements, the President can oblige and thereby empower himself to perform any action he considers appropriate. ${ }^{274}$ First,

${ }^{271}$ See supra text accompanying notes 146-48, 178-86.

272 See supra text accompanying notes 213-16.

${ }^{273}$ In fact, objection was made to the list of exceptions appended to the House bill in its first form, see supra text accompanying note 152 , because it was unduly solicitous towards foreign states at the expense of American citizens. See CoNG. GLoBs, 40th Cong., 2d Sess. 1017 (1868) (remarks of Rep. Chanler):

Mr. Speaker, is not this remarkably liberal of the honorable gentlemen? He not only brings in 'a bill concerning the rights of American citizens in foreign states,' but he undertakes to protect those States against our citizens. . . . [I]t seems practically to be a bill 'to redress the wrongs of foreign States.....'

The offending list was dropped.

${ }^{274}$ Such an argument might be based on a tortured analogy to Missouri v. Holland, 252 U.S. 416 (1920), in which the Supreme Court interpreted the treaty power as an independent grant of authority to the federal government, so that Congress could validly enact a statute to implement a treaty even if the statute otherwise exceeded the reach of other grants of legislative power like the commerce clause. Id. at 432. In the absence of a treaty, it is generally recognized that the President's power to make executive agreements with the concurrence of Congress extends at least as far as the legislative competence of Congress, but that executive agreements made without any legislative approval on subjects not ex- 
the senators' discussions of negotiation as a means of obtaining release show that they were not thereby giving their consent in advance to any agreement the President might reach with a foreign power. Rather, they saw negotiation as an option already possessed by the President, one that a statutory grant of discretion would not foreclose. ${ }^{275}$ Second, history demonstrates that the Senate did not regard the Citizens in Foreign States Act as rendering superfluous its advice and consent to ratification of the naturalization protocol and the subsequent treaty by which the President finally settled the controversy with Great Britain. ${ }^{278}$ Nor did the Senate view itself as bound to accept the companion agreement for the settlement of the Alabama claims, which it overwhelmingly rejected on April 13, 1869, the same day it consented to the naturalization protocol. 277 The Act thus preserves the President's usual powers to form international agreements in a manner consistent with constitutional limits on his individual authority, but does not directly augment his ability to dispense with the express consent of Congress. ${ }^{278}$

The scope of the power delegated may thus be summarized as

pressly confided to the President by the Constitution raise separation-of-powers questions requiring close scrutiny like that given by the Supreme Court in Dames \& Moore. See REstatembnt (Second) of the Forkign Rejations Law of the Unitbd Statbs §§ 199-121 (1965); L. HzNkin, Forbign Aprairs aNd the Constitution 174-75, 177-79 (1972). In fact, such questions are rarely litigated.

${ }^{276}$ See supra note 242.

278 The Senate gave its advice and consent to the Protocol on April 13, 1869, B. JBNkINS, supra note 70 , at 279 , and to the treaty on July $8,1870,12$ Treaties AND OTHBR INTERnational AgreEments of the UnITED States of AMERICa 158 (C. Bevans ed. 1974).

${ }^{277}$ See B. JEnkins, supra note 70, at 279. The implication of Dames \& Moore, however, is that if the President had settled the Alabama claims by executive agreement as part of a package resolving the naturalization controversy and had not requested approval from the Senate or the full Congress, his settlement would have remained effective until Congress acted to overturn it. This conclusion would be based on an acquiescence rationale, not on the authority delegated by the Citizens in Foreign States Act. See supra text accompanying notes 31-33. The Alabama claims, though not logically connected to the naturalization controversy, were part of the same emotional climate against Great Britain; they were linked strategically to the naturalization issue by Secretary of State Seward and rhetorically in the congressional debates. See B. JENKINS, supra note 70, at 253, 278; Cong. GloBE, 40th Cong., 2d Sess. 1017 (1868) (remarks of Rep. Chanler) ("On the topic of 'locomotion' the gentleman is very explicit and daring, but on the release of our prisoners and payment of the Alabama claims he is very silent."); id. at 4238 (remarks of Sen. Stewart) ("if we do have [war with Great Britain as a result of the House bill] I think we shall make some reprisals on account of the Alabama").

278 Indirectly, however, the Act is a factor in determining the extent of congressional acquiescence in presidential action for the purpose of separation-of-powers analysis. See supra text accompanying note 30 . 
follows. The President is given broad discretion in choosing among diplomatic, military, and economic means of bringing pressure or influence to bear on a foreign state that has imprisoned American citizens unlawfully. His response must be within constitutional bounds, ${ }^{279}$ must not amount to an act of war, ${ }^{280}$ and must be a direct means for affecting the conduct of the foreign state rather than a scheme of domestic regulation intended ultimately to make release of American citizens more likely. ${ }^{281}$ When he employs sanctions requiring domestic compliance, such as suspension of commercial relations, the statute presumably supports regulations to enforce them, but interference with activities by Americans is only authorized as an incident of endeavors aimed at the foreign state.

\section{The Act and the Iranian Agreements}

In Dames \& Moore v. Regan, ${ }^{282}$ the Supreme Court upheld the President's actions in vacating attachments and suspending litigation of claims against Iran without relying on the Citizens in Foreign States Act as a source of express congressional authorization. ${ }^{283}$ Because the President attempted to assert section 1732 as a basis for his orders, ${ }^{284}$ however, and because the range of undertakings involved in the Algerian Declarations provides so varied a spectrum of real-life hypotheticals for testing the limits of the statute, ${ }^{285}$ it would be profitable to examine the extent to which the Act could supply express authority for various elements of the Iranian agreements, the executive orders, and the regulations promulgated thereunder. ${ }^{\mathbf{2} 6}$

279 For example, the President may not order execution of citizens of the foreign state, regardless of whether such reprisals would technically be acts of war.

280 This exception, of course, is in the statute itself.

281 Compare Senator Conkling's facetious example of "expend[ing] moneys otherwise in such modes as he might think were conducive to the harmony of nations and the establishment of the rights of American citizenship." Cong. GLoBE, 40th Cong., 2d Sess. 4333 (1868); see supra text accompanying note 217.

${ }^{282} 101$ S. Ct. 2972 (1981).

${ }^{283}$ See supra text accompanying notes 30-33.

${ }^{284}$ See Exec. Order No. 12,294, 46 Fed. Reg. 14,111-12 (1981) (Pres. Reagan); Exec. Orders Nos. 12,276-12,284, 46 Fed. Reg. 7913-30 (1981) (Pres. Carter).

${ }^{285}$ The agreement obliges the United States, inter alia, to refrain from intervention in Iran's internal affairs, to return frozen Iranian assets, to revoke trade sanctions, to withdraw claims before the International Court of Justice, to bar litigation on certain claims by American nationals against Iran or by nonnationals in American courts, and to freeze assets of the former Shah of Iran so that Iran can seek their return through litigation. Declaration I, supra note 2 , IT $1,3-6,10,11,12$.

${ }^{288}$ See Declarations I \& II, supra note 2; Exec. Order No. 12,294, 46 Fed. Reg. 14,111 


\section{A. Invoking the Statute}

The threshold question is whether the statute applies at all; that is, whether the detention of the American hostages was "by or under the authority of any foreign government" and whether it was "wrongful and in violation of the rights of American citizenship." The answer to the first question is obviously yes, at least by the time of the Algerian Declarations. Although it is possible that the initial seizure of the American embassy was an act of private terrorism, the Iranian government associated itself with the hostage-taking soon thereafter. ${ }^{287}$ The second question, which gave the Supreme Court some pause in Dames \& Moore ${ }^{288}$ must also be answered affirmatively in light of the legislative history: seizure of American embassy personnel in defiance of an immunity universally recognized in international law, and subjection of them to extended confinement under often brutal conditions without legal procedures of any kind constitutes, to put it mildly, an infringement of privileges due to them as United States citizens under international law. ${ }^{289}$ That Americans alone were singled out for this treatment does not make the outrage any more a recognition of American citizenship than was the British arrest on suspicion of Irish-Americans visiting Ireland in the 1860's during the suspension of habeas corpus. ${ }^{200}$

(1981); Exec. Orders Nos. 12,276-12,284, 46 Fed. Reg. 7913-30 (1981); Iranian Assets Control Regs., 31 C.F.R. 535 (1981).

Another interesting question is whether the Act could be interpreted as congressional consent for the attempted hostage rescue mission ordered by President Carter in April 1980. Although numerous members of the Fortieth Congress probably would have applauded this military incursion, see supra note 209; supra text accompanying notes 148, 216, it appears to be precisely the sort of "act of war" that Senator Williams's modification was designed to leave to congressional supervision. See supra note 216; supra text accompanying note 197. On the other hand, when called upon to explain President Carter's failure to consult with Congress before authorizing the expedition, as contemplated by the War Powers Resolution of 1973, the administration argued that it was not a "sustained military action," but merely an "anti-terrorist rescue operation for humanitarian purposes." See The Situation in Iran: Hearings Before the Senate Comm. on Foreign Relations, 96th Cong., 2d Sess. 3 (1980) (statement of Warren Christopher, Acting Secretary of State).

${ }^{287}$ See The Iran Agreements: Hearings Before the Senate Comm. on Foreign Relations, 97th Cong., 1st Sess. 8-9 (1981). For the Citizens in Foreign States Act to provide authority for the asset freeze of November 14,1979, however, it would be necessary for the imprisonment to have become the act of the Iranian government by that date. The point is purely academic, of course, because the authority for the freeze derives wholly from the International Emergency Economic Powers Act ("IEEPA"). See infra note 293.

$280101 \mathrm{~S}$. Ct. at 2985.

189 See supra notes $252-54$ and accompanying text.

200 See supra note 88 and accompanying text. 


\section{B. The Freeze and Release of Iranian Assets}

Once the Citizens in Foreign States Act is available to justify presidential actions, the focus of inquiry shifts to whether specific exercises of power are validly characterized as means to obtain release of the hostages. ${ }^{291}$ An easy example of conduct that could come within the statute is the presidential freeze and subsequent release of Iranian assets. The use of government sanctions against Iranian property in this country to obtain leverage over the Iranian leadership offers a paradigm of the flexible authority for direct action conferred by the Act. Although vacating the post-freeze attachments and returning the assets were conciliatory and not hostile acts, the authority that supported the freeze must also legitimate the thaw to effectuate the release of the hostages. The intervening rights of claimants who benefited from the attachments were expressly made revocable by the regulations that permitted attachments in spite of the freeze, and no further presidential authority is required to subordinate the rights of these claimants to the renewed rights of the Iranian government. ${ }^{202}$ Thus, if there were no International Emergency Economic Powers Act ("IEEPA"), an opinion upholding the return of the assets on the basis of the Citizens in Foreign States Act could take precisely the same form as the Supreme Court's opinion on that point in Dames \& Moore. ${ }^{293}$

291 See supra notes 279-81 and accompanying text.

${ }^{292}$ Cf. Dames \& Moore v. Regan, 101 S. Ct. 2972, 2984 n.6 (1981).

209 Id. at 2982-84.

Because, however, there is an IEEPA, it becomes necessary to ask whether the later statute impliedly withdraws authority granted by the Citizens in Foreign States Act. Although the 1868 Act is limited to a class of international emergencies involving imprisonment of American citizens, and therefore might in a sense be considered more "specific" than the IEEPA, from another point of view the latter is the more "specific" statute because it attempts to state explicit bounds on the timing and the scope of presidential authority to interfere with international trade or with the property of a foreign state and its nationals. The legislative history of the IEEPA documents congressional concern with curbing the essentially limitless discretion the President had exercised under the Trading with the Enemy Act. See, e.g., H.R. Rep. No. 459, 95th Cong., 1st Sess. 7-9 (1977). As a result, the 1868 Act should probably no longer be read as authorizing actions regarding property of foreign states that would be forbidden under the IEEPA, on the principle that specific legislation supplants more general provisions. See, e.g., HCSC-Laundry v. United States, 450 U.S. 1, 6 (1981). This conclusion does not affect the analysis of the Iranian agreements, for the Supreme Court held in Dames \& Moore that the IEEPA did authorize the release of the assets, $101 \mathrm{~S}$. Ct. at 2984, and that the IEEPA did not apply to the claims settlement because the claims were in no sense transactions involving Iranian property, id. at 2984-85. See Charles T. Main Int'l, Inc. v. Khuzestan Water \& Power Auth., 651 F.2d 800, 809 n.13 (1st Cir. 1981). The IEEPA would be equally controlling on the subject of the assets of the former 


\section{Claims Settlement}

The settlement of claims by United States nationals against Iran, either of a commercial nature or arising from the hostagetaking itself, ${ }^{294}$ presents a different question. The Algerian Declarations effected a settlement of claims of both United States nationals and the United States itself against Iran. These latter, purely governmental claims include the action brought in the International Court of Justice and claims for damages to United States property arising out of the embassy seizure. ${ }^{205}$ Obviously, nothing in the Citizens in Foreign States Act forbids the settlement of these governmental claims. Resort to the International Court of Justice constituted an effort to obtain the release of the hostages, and dismissal of that suit after their release, like the unfreezing of the assets, would come within the statute. The same would be true of damage claims based on the embassy seizure, at least to the extent that they were pressed during the negotiations; in fact, assertion of claims for reparations may be so implicit in the negotiation process that a release of liability for the violation of international law is always authorized by the statute. ${ }^{296}$

The independent lawsuits brought by private litigants on claims whose only connection to the hostage-taking was that they both arose somehow out of the Islamic Revolution in Iran, how-

Shah. See supra note 285.

294 The Algerian Declarations prescribe different treatment for different classes of claims by United States nationals against Iran. The largest class of claims are those arising out of "debts, contracts (including transactions which are the subject of letters of credit or bank guarantees), expropriations or other measures affecting property rights," Declaration II, supra note 2 , art. II, II 1 ; these are to be submitted to a special arbitral tribunal, unless the contracts expressly require adjudication by the courts of Iran. Claims arising out of "(1) the seizure of the hostages on November 4,1979, (2) their subsequent detention, (3) injury to United States property or property of United States nationals within the United States Embassy compound in Tehran after November 3,1979, or (4) injury to United States nationals or their property as a result of popular movements in the course of the Islamic Revolution in Iran which were not an act of the Government of Iran," have been wholly waived. Exec. Order No. 12,283, 46 Fed. Reg. 7927 (1981); Declaration I, supra note 2, I 11. But see infra note 313. Although the Supreme Court's opinion in Dames \& Moore upholding the settlement of commercial claims was "buttressed by the fact that the means chosen by the President . . . provided an alternate forum, the Claims Tribunal, which is capable of meaningful relief," $101 \mathrm{~S}$. Ct. at 2990 , most of the Court's rationale is broad enough to include the waiver of claims in the second class as well. Indeed, the contract in Dames \& Moore may have required submission to Iranian courts, precluding jurisdiction in the tribunal, although the claim has not been absolutely waived. See id. at 2979 n.4.

20s See Declaration I, supra note 2, II 11.

206 This would presumably include the claims of the hostages themselves against Iran for their mistreatment. 
ever, do not appear to be acts of the United States government at all. So far the government has not alleged that it coordinated or encouraged these suits as an adjunct to the asset freeze to increase the economic pressure on Iran to free the hostages. ${ }^{297}$ If the only similarity between these private lawsuits and the government's own hostage claims was that they had a common defendant, the sacrifice of the private claims cannot be characterized as an authorized means for obtaining release except on the theory that the statute empowers the President to agree to give the foreign adversary whatever it asks for. But it has already been observed that the Fortieth Congress regarded the executive as possessing sufficient power to negotiate on his own initiative and that the Citizens in Foreign States Act does not convey an advance consent to every agreement the President might see fit to negotiate. ${ }^{289}$ Accordingly, the statute itself neither increases nor diminishes the President's independent authority to settle unrelated private claims as an incentive for release of American citizens. The Supreme Court has now held that the President does have such authority, at least in the absence of congressional disapproval, ${ }^{299}$ but this power does not come directly from the 1868 statute.

\section{What is a "Settlement"?}

Before turning to another aspect of the agreements, it would be worthwhile to comment on the use of the word "settlement" as a description of the President's treatment of the private claims against Iran. In no instance did he receive a sum of money for transmittal to a private party asserting one of the settled claims. Certain claims, including those of the individual hostages, were wholly abandoned, and American nationals are expressly forbidden to prosecute these claims in any court in the world. ${ }^{300}$ Other claims, arguably eligible for submission to the arbitral tribunal, have merely been "suspended" pending its adjudication, and until that time they are available for use as a counterclaim or set-off

297 Such a claim by the government might not be totally lacking in plausibility. For example, the judicial orders of attachment against Iranian assets after the freeze were only possible because of an express (and revocable) license granted under the Iranian Assets Control Regulations See 31 C.F.R. $\$ \S 535.218, .504$ (1980). But the claim was not made in the Iranian assets litigation.

${ }^{288}$ See supra notes $260-69$ and accompanying text.

${ }^{299}$ Dames \& Moore v. Regan, 101 S. Ct. 2972, 2991 (1981).

${ }^{300}$ Declaration I, supra note 2, I 11; Exec. Order No. 12,283, 46 Fed. Reg. 7927 (1981); 31 C.F.R. § 535.216 (1981). 
should any Iranian government instrumentality be foolish enough to bring suit against the claimant. ${ }^{301}$ For this reason, private litigants and at least one court have argued that no real settlement of these claims was effected by the Algerian Declarations; rather, they argue that the agreement merely accomplished a change of forum, and that the significance of the "suspension" of the litigation is that the executive has withdrawn jurisdiction over these claims from the state and federal courts of the United States. ${ }^{302}$

The question is not an idle one of semantics, because if the Iranian agreements were actually a matter of executive interference with jurisdiction, it is likely that they would be squarely in conflict with the Foreign Sovereign Immunities Act of 1976. ${ }^{303}$ This statute was intended to eliminate the role of the executive in determining whether a suit against a foreign nation is within the jurisdiction of the courts or is barred by the doctrine of sovereign immunity. After three decades of total judicial deference to the State Department's suggestions of immunity, ${ }^{304}$ Congress sought to legislate "the sole and exclusive standards to be used in resolving questions of sovereign immunity raised by foreign states before Federal and State courts in the United States."

An executive agreement to exclude certain claims against Iran from the jurisdiction of state and federal courts is thus at the dangerous lower end of Justice Jackson's Youngstown spectrum, ${ }^{308}$ where the President's power is "at its lowest ebb," and where courts can sustain his action "only by disabling the Congress from acting upon the subject." ${ }^{302}$ In a conflict between the President and the Congress over their relative authority to control the juris-

\footnotetext{
${ }^{301}$ See Exec. Order No. 12,294, 46 Fed. Reg. 14,111-12 (1981); 31 C.F.R. § 535.222 (1981); supra note 294.

${ }^{302}$ See, e.g., Marschalk Co. v. Iran Nat'l Airlines Corp., 518 F. Supp. 69, 84 (S.D.N.Y.), certified questions answered, 101 S. Ct. 3154, rev'd, 657 F.2d 3 (2d Cir. 1981).

sos Pub. L. No. 94-583, §§ 2(a), 4(a), 90 Stat. 2891, 2891-97 (codified at scattered sections of the U.S. Code, including 28 U.S.C. $\$ \S 1330,1602-1611$ (1976)).

sor The Supreme Court had decreed unquestioning deference to the State Department's decisions to submit or to withhold "suggestions of immunity" in cases against foreign states in Ex parte Peru, 318 U.S. 578, 586-87 (1943).

${ }^{\text {sos }}$ H.R. REP. No. 1487, 94th Cong., 2d Sess. 12 (1976). The statutory rules are explicitly made "[s]ubject to existing international agreements to which the United States is a party at the time of enactment of this Act," 28 U.S.C. $\$ 1604$ (1976); the legislative history demonstrates that this wording was deliberately intended to preclude the appearance of authorizing future agreements. H.R. REP. No. 1487, 94th Cong., 2d Sess. 10 (1976).

${ }^{300}$ See supra notes 24-25 and accompanying text.

307 Youngstown Sheet \& Tube Co. v. Sawyer, 343 U.S. 579, 637-38 (1952) (Jackson, J., concurring).
} 
diction of the federal courts, Congress has the advantage of explicit constitutional language. Article I, section $8^{308}$ and article III, section 1 expressly give Congress the power to constitute, ordain, and establish inferior federal courts. ${ }^{309}$ Nor can it be argued that the Framers did not contemplate the foreign affairs implications of jurisdiction, for they were careful to include the alienage jurisdiction within the federal judicial power and to give the Supreme Court original jurisdiction in cases affecting ambassadors, other public ministers, and consuls. ${ }^{310}$ The limits of Congress's power to manipulate federal jurisdiction for dubious substantive ends is a current subject of controversy, ${ }^{\text {s11 }}$ but the suggestion that the President himself has inherent powers over jurisdiction that take precedence over those of Congress would truly be a novel contribution to the debate.

Most courts, however, including the Supreme Court, have recognized submission of international claims to arbitration as an historically sanctioned method for resolving them, and have characterized "suspension" as a substantive undermining of the claim rather than as a jurisdictional or procedural obstacle to litigating it. ${ }^{312}$ Whether the agreement to arbitrate is described as a final "settlement" of the claim or as an initiation of the settlement process, it is not merely an executive interference with federal jurisdiction, now banned by the Foreign Sovereign Immunities Act.

\section{E. Claims of Foreign Nationals}

The same cannot be said, unfortunately, of another element of the Iranian Assets Control Regulations and the executive orders

308 U.S. CoNST. art. I, \& 8, cl. 9.

sos "The Congressional power to ordain and establish inferior courts includes the power 'of investing them with jurisdiction either limited, concurrent, or exclusive, and of withholding jurisdiction from them in the exact degrees and character which to Congress may seem proper for the public good.' "Lockerty v. Phillips, 319 U.S. 182, 187 (1943) (quoting Cary v. Curtis, 44 U.S. (3 How.) 236, 245 (1845) (emphasis added).

s10 U.S. ConsT. art. III, $\S 2$, para. 1.

s11 See, e.g., Sager, Foreword: Constitutional Limitations on Congress' Authority to Regulate the Jurisdiction of the Federal Courts, 95 HaRv. L. Rav. 17 (1981).

312 See, e.g., Dames \& Moore v. Regan, 101 S. Ct. 2972, 2991-92 (1981); American Int'l Group, Inc. v. Islamic Republic of Iran, 657 F.2d 430, 441-43 (D.C. Cir. 1981); Charles T. Main Int'l, Inc. v. Khuzestan Water \& Power Auth., 651 F.2d 800, 810-13 (1st Cir. 1981). None of these cases confronted the specific argument that the claim suspension is jurisdictional because, until the tribunal acts, the claim is available for purposes of set-off or counterclaim. Limiting a cause of action to defensive rather than independent use under certain circumstances is not unprecedented and need not be based on jurisdictional grounds. See, e.g., Younger v. Harris, 401 U.S. 37 (1971). 
implementing the Algerian Declarations. The regulations seek to prevent, among other things, prosecution of any claim against Iran arising out of "[i]njury to United States nationals or their property as a result of popular movements in the course of the Islamic Revolution in Iran which were not an act of the Government of Iran."31s American nationals are prohibited from prosecuting such claims anywhere in the world, while nonnationals are prohibited from prosecuting those claims "in any court within the United States."314 Although traditional international practice gives the United States authority to settle the claims of American nationals against Iran, ${ }^{315}$ no such tradition would support the assertion of a right to settle claims of foreigners against Iran. One might hypothesize, for example, a wrongful death action or claim for loss of consortium by the British spouse of an American killed or injured in the course of the Islamic revolution. ${ }^{316}$ Under international law, the President has no power to release such a claim that the courts

312 31 C.F.R. $\$ 535.216(a)(4)$ (1981). The authors have not examined texts of the Algerian Declarations in languages other than English, but on the basis of the English text submitted to various courts during the Iranian assets litigation, it appears that this provision may be more broadly worded than the Declarations require. The first Declaration, after obliging the United States to "bar and preclude" itself or "a United States national" from litigating claims arising out of the hostage-taking, which is described as "the seizure of the 52 United States nationals on November 4, 1979," turns to claims for damage "to United States property or property of the United States nationals within the embassy," and "injury to the United States nationals or their property as a result of popular movements." Declaration I, supra note 2, I11. Finally, the United States is also to bar litigation in American courts of claims "asserted by persons other than the United States nationals arising out of the events specified in the preceding sentence." Id. Although confessing their ignorance of the relevant foreign languages, the authors suggest that each appearance of the phrase "the United States nationals" in the passage may refer exclusively to the hostages, and not to damage claims of American nationals generally, as the regulations cited above and President Carter's Executive Order No. 12,283, 46 Fed. Reg. 7927 (1981), seem to imply.

${ }^{314} 31$ C.F.R. \& 535.216(a), (b) (1981).

${ }^{315}$ It is a maxim of international law that the claim of the national may be waived or settled by the sovereign. See, e.g., Restatement (Second) of the Foreign Relations Law OF THE UNITED STATES \$ 205 (1965). The validity of this notion as a matter of domestic law may be tested in litigation in the Court of Claims if the American claimants come home dissatisfied from the Iranian claims tribunal. See supra note 33.

218 These illustrations are inevitably artificial, and it is probable that no such claims will ever be brought. Nonetheless, the conscientious reiteration of the prohibition in executive orders and regulations suggests that at least someone considered these clains likely enough to be worth the effort to prevent them. The creative genius of the common law might find a special duty sufficient to attach liability to the Iranian government for failure to prevent injury to American citizens arising out of revolutionary acts that were not its own. Cf. Dabis v. San Francisco Redevelopment Agency, 50 Cal. App. 3d 704, 709, 122 Cal. Rptr. 800, 803 (1975) (agency liable to neighbors when burglaries resulted from failure to board up vacant building). 
of the United Kingdom would be obliged to respect.

The Citizens in Foreign States Act is of little help to the President here, either. Regulation of jurisdiction over a claim that the President has no power to assert and no power to compromise can hardly be characterized as a means of exerting pressure on Iran. This jurisdictional agreement therefore finds even less support in the 1868 statute than does the settlement of unrelated claims of American nationals.

It is possible that the damage claim of the hypothetical British spouse against Iran could not have been brought in United States courts even if the President had not attempted to ban such litigation. Most likely, it would be precluded by the conditions for waiver set forth in the Foreign Sovereign Immunities Act. ${ }^{317}$ If so, the regulations are redundant, and any executive overreaching in their promulgation is academic and totally harmless. If it is found that Iran has waived its sovereign immunity, ${ }^{\mathbf{3 1 8}}$ however, the regulations prohibiting suits by nonnationals in American courts are squarely in conflict with the Foreign Sovereign Immunities Act. The Supreme Court's holding in Dames \& Moore would not support a finding of congressional acquiescence in the President's action, because the Court's own careful distinction between claims settlement and regulation of jurisdiction makes the long-standing tradition of claims settlement unavailable as evidence that Congress has tolerated executive interference with federal jurisdiction. ${ }^{319}$ The proper deus ex machina for this predicament is proba-

317 The statute makes foreign states immune from the jurisdiction of American courts unless certain exceptions are satisfied. These include cases, among others, "in which the foreign state has waived its immunity either explicitly or by implication," 28 U.S.C. § 1605(a)(1) (1976); "in which the action is based upon a commercial activity carried on in the United States by the foreign state," $i d . \$ 1605(a)(2)$; or "in which rights in property taken in violation of international law are in issue and that property . . . is present in the United States in connection with a commercial activity carried on in the United States by the foreign state," $i d$. $\$ 1605(a)(3)$.

318 Some of the courts in the Iranian cases were innovative in finding waivers of sovereign immunity. See, e.g., New Eng. Merchants Nat'l Bank v. Iran Power Generation \& Transmission Co., 502 F. Supp. 120, 129 (S.D.N.Y. 1980) (presidential freeze stripped Iran of its immunity from prejudgment attachments), remanded, 646 F.2d 779 (2d Cir.), reinstated sub nom. Marschalk Co. v. Iran Nat'l Airlines Corp., 518 F. Supp. 69 (S.D.N.Y.), certified questions answered, $101 \mathrm{~S}$. Ct. 3154, rev'd, 657 F.2d 3 (2d Cir. 1981); American Int'l Group, Inc. v. Islamic Republic of Iran, 493 F. Supp. 522, 526 (D.D.C. 1980) (Iran is "alter ego" of commercial instrumentality and therefore subject to its waiver), vacated in part, 657 F.2d 430 (D.C. Cir. 1981).

${ }^{319}$ In fact, however, the relevant question may be regulation of state court jurisdiction and not federal jurisdiction at all. At least one court has held that the Foreign Sovereign Immunities Act is itself unconstitutional to the extent that it attempts to confer jurisdiction 
bly the IEEPA. Although the Supreme Court rejected this statute as a basis for the claims settlement in Dames \& Moore because a lawsuit between an American plaintiff and a foreign defendant is not "the 'exercising' of a 'right' with respect to 'property' " of the foreign defendant, ${ }^{320}$ a lawsuit between two foreign parties is the exercising of a right with respect to property of the foreign plaintiff. ${ }^{221}$ Thus Dames \& Moore is distinguishable, and the IEEPA may supersede the Foreign Sovereign Immunities Act in the limited context of a national emergency.

\section{ConCLUSION}

In Dames \& Moore v. Regan, the Supreme Court wisely resisted the temptation to sidestep a major constitutional controversy by stretching an obscure nineteenth century statute to the widest possible limits of its language. The government's sweeping claims for the "Hostage Act" as a plenary delegation of legislative power have an immediate ring of implausibility, and even a brief glance at the legislative history demonstrates that they caricature the intent of Congress. A closer study of the relevant materials indicates that the Citizens in Foreign States Act merely empowers and prods the President to exert pressure on a foreign nation that has wrongfully imprisoned American citizens.

The harm that a hasty acceptance of the government's argument might have created should not be minimized. It is true that the Supreme Court's holding in Dames \& Moore expands the President's inherent authority over foreign relations beyond the scope required by the Court's infrequent prior holdings. But the built-in

on the federal courts in suits between an alien and a foreign state with no American citizens as parties and no federal question at issue. Verlinden B.V. v. Central Bank of Nigeria, 647 F.2d 320, 325-26 (2d Cir. 1981), cert. granted, 102 S. Ct. 997 (1982) (No. 81-920). But see Mashayekhi v. Iran, 515 F. Supp. 41, 42-43 (D.D.C. 1981) (even in ordinary contract action, United States-Iran Treaty of Amity and international tension create sufficiently strong federal interest to confer jurisdiction); cf. National Mut. Ins. Co. v. Tidewater Transfer Co., 337 U.S. 582, 603-04 (1949) (holding, with no majority rationale, that Congress can deem citizens of the District of Columbia citizens of a state for diversity purposes).

s20 See supra note 28.

s21 See, e.g., Propper v. Clark, 337 U.S. 472, 479-80 (1949) (decided under the Trading with the Enemy Act). Nothing in the IEEPA limits the President's regulatory powers over foreign property to that belonging to citizens of an enemy state. See United States v. Quong, 303 F.2d 449, 503 (6th Cir. 1962); United States v. Yoshida Int'l, Inc., 526 F.2d 560, 573 n.17 (C.C.P.A. 1975); United States v. Broverman, 180 F. Supp. 631, $634-35$ (S.D.N.Y. 1959) (all decided under the Trading with the Enemy Act). This aspect of the Iranian regulations is unlikely to effect a compensable taking, because the hypothetical alien remains free to sue Iran in any court in any country in the world except the United States. 
inertia that characterizes the congressional process would present a tremendous obstacle to timely legislative correction of future executive overreaching under an all-encompassing Hostage Act. In fact, the Supreme Court's narrow holding does little to encourage presidential self-aggrandizement and in practical terms expands the President's power less than any of the statutory alternatives would have.

The Citizens in Foreign States Act, though less talismanic than some of its advocates insist, turns out to be an interesting enactment in its own right. Born of colorful incidents in American history, it guarantees the equality of naturalized citizens. Like other legal products of its period, the Act is intended as a message of freedom to Americans, and if it gives cause for anxiety, it should be in hostile foreign capitals and not our own. 